
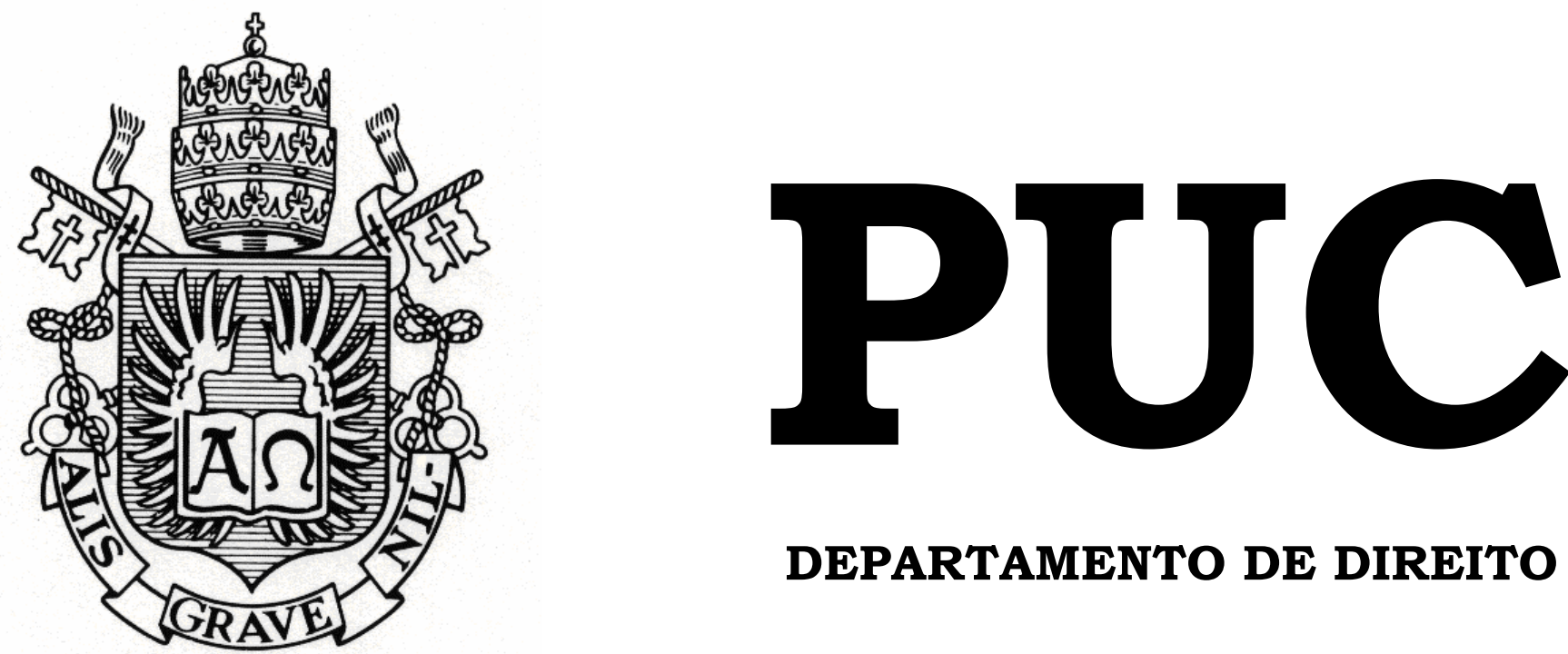

DEPARTAMENTO DE DIREITO

Assédio Moral: A subversão do poder de comando no contrato de trabalho

por

Jacqueline de Azevedo Silva

ORIENTADOR(A): Irineu Zibordi

2009.2

PONTIFÍCIA UNIVERSIDADE CATÓLICA DO RIO DE JANEIRO

RUA MARQUÊS DE SÃO VICENTE, 225 - CEP 22453-900

RIO DE JANEIRO - BRASIL 


\title{
Assédio Moral: A subversão do poder de comando no contrato de trabalho
}

\author{
por
}

JACQUELINE DE AZEVEDO SILVA

Monografia apresentada

ao

Departamento de Direito da Pontificia Universidade Católica do Rio de Janeiro (PUC-Rio) para a obtenção do Titulo de Bacharel em Direito.

Orientador(a): Irineu Zibordi 
Ao meu Deus, porque dEle, por Ele e para Ele são todas as coisas. 


\section{Agradecimentos}

É preciso reconhecer o apoio e a colaboração de certas e providenciais pessoas, que sacrificaram tempo e abriram mão de suas rotinas, para dar vida a este projeto.

Em primeiro lugar, agradeço ao meu orientador, Mestre Irineu Zibordi, que jamais se olvidou de compartilhar comigo toda sua cultura jurídica. Foram lições preciosas e edificantes, não somente para esta monografia, mas para um modelo ilibado de vida profissional.

Meus colegas de sala de aula, que representaram escape às pressões acadêmicas, renovando meu ânimo para cada novo desafio que se abria, até culminar neste trabalho.

Agradeço, ainda, à Pontifícia Universidade Católica do Rio de Janeiro, que, em cinco anos, tornou-se meu segundo lar, onde encontrei referenciais para compor uma profissional mais competente e uma cidadã melhor.

Por fim, com um carinho particular, agradeço aos meus pais, irmã, namorado e todos os demais, indispensáveis, que depositaram confiança no meu potencial e deram incondicional apoio nos momentos de aflição. 
O local de trabalho constitui o último campo de batalha em que uma pessoa pode matar outra, sem qualquer risco de chegar a ser processada diante de um tribunal.

Heinz Leymann 


\section{Resumo}

O presente estudo se propõe a abordar a construção e a degeneração das relações de poder travadas dentro do contrato de trabalho. Para tanto, parte-se da análise da legitimação histórica e jurídica do estado de subordinação do empregado ao empregador, bem como de seus limites constitucionais e contratuais.

Diante de tais observações, passa-se a esmiuçar o assédio moral como verdadeiro atentado à dignidade humana, com repercussões no pacto laboral e na saúde do trabalhador. Com o resultado dessa investigação, pretende-se indicar as principais tendências - doutrinárias, jurisprudenciais e legislativas no combate à violência moral no ambiente de trabalho, de modo a otimizar a prevenção e os mecanismos de reparação.

\section{Palavras-chave}

Assédio moral; dignidade do trabalhador; saúde do trabalhador; contrato de trabalho; poder diretivo; subordinação; responsabilidade trabalhista. 


\section{Abstract}

The present paper intends to discuss the construction and the degeneration of the power relations under an employment contract. Therefore, it starts with an analisys of the historical and legal legitimacy of the subordination of the agent to the principal, and it's constitutional and contractual limits.

Before these observations, it starts to scrutinize moral harassment as actual attack against human dignity, with reppercussion in the labor agreement and the worker's health. With the results of this investigation, it intends to indicate the main tendencies - doctrinal, jurisprudential and legislative - in the struggle against the moral violence in the work environment, optimizing the prevention and the repair mechanism.

\section{Keywords}

Moral harassment; worker's dignity; worker's health; labor agreement; directing power of the principal; subordination; respondeat superior. 
1 TUTELA CONSTITUCIONAL DO TRABALHADOR.......... 13

1.1 A dignidade da pessoa humana....................................... 13

1.2 Reverberações da dignidade humana nas relações de trabalho

1.2.1 Proibição de discriminar e liberdade de expressão e opinião do trabalhador.....

1.2.2 Respeito à intimidade e vida privada do trabalhador.

1.2.3 Preservação da honra e imagem do trabalhador..

1.3 Garantias específicas do trabalhador............................... 33

1.4 Previsões internacionais de proteção do trabalhador..... 37

2 O PACTO LABORAL COMO FONTE DE PODERES E DEVERES.

$2.1 \mathrm{O}$ contrato de trabalho..................................................... $\quad 39$

2.2 Deveres do empregado................................................... 41

2.3 A subordinação do empregado dentro do contrato de trabalho....................................................................... 43

2.4 Poderes e deveres do empregador.................................. 46

2.5 Conseqüências do descumprimento dos deveres contratuais

3 A VIOLÊNCIA MORAL PROVOCADA PELOS EXCESSOS DO PODER DIRETIVO .................................... 54

3.1 Contextos contemporâneos............................................. 54

3.2 Conceito................................................................... 56

3.3 A vítima do assédio moral............................................. 59

$3.4 \mathrm{O}$ agressor.................................................................... 61

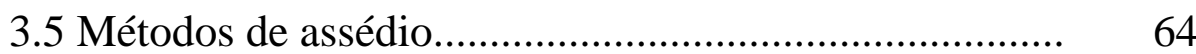

4 UMA LEITURA JURISPRUDENCIAL E LEGISLATIVA DAS CONSEQÜÊNCIAS DO ASSÉDIO MORAL................... $\quad 66$

4.1 Conseqüências para o agressor....................................... $\quad 66$

4.2 Conseqüências para o assediado........................................ 73 


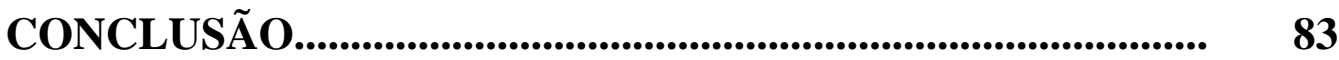

BIBLIOGRAFIA.................................................................................. 89 


\section{Introdução}

A realidade da vivência social entre indivíduos diferentes, seja quanto às aspirações e potencialidades, revela que é possível destruir alguém apenas com palavras, subentendidos ou mesmo olhares. Trata-se do assédio moral, engendro violento focado quase que exclusivamente na psique humana, de efeitos nefastos e variados.

As sutis agressões de ordem psicológica podem ser verificadas em qualquer esfera de interação humana, como, por exemplo, dentro de uma unidade familiar, numa vizinhança ou mesmo no ambiente de trabalho. Afinal, como militou Jean-Jacques Rousseau ${ }^{1}$, o homem é, originariamente, um ser autônomo e puro, que se mutila ao ser inserido numa comunidade. Avesso a essa ordem artificial, o homem descobriria em si impulsos destrutivos, que são lançados contra seus pares, em disputa por espaço, poder e posição.

Seguindo tal ordem de idéias, o ambiente laborativo nos desperta maior inquietude, tendo em vista a natureza e vicissitudes das relações travadas naquela arena. Durante uma atividade produtiva voltada para o lucro, ideologias materialistas vão, cada vez mais, reduzindo o valor e o significado do homem dentro da moderna organização do trabalho.

Essa concepção de trabalho humano já traz, por si só, deturpações. Não se pode permitir o abandono da noção de trabalho como um instrumento para se ganhar a vida, e não de se perdê-la². É através do trabalho que - muito além de um mero patrimônio material -, o homem constrói valores sociais, com reverberações múltiplas, inclusive no seu processo de dignificação.

\footnotetext{
${ }^{1}$ ROUSSEAU, Jean-Jacques. Discurso sobre a origem das desigualdades entre os homens. São Paulo: Nova Cultural, 1987. p. 45.

2 MELO, Raimundo Simão de. Direito ambiental do trabalho e saúde do trabalhador: responsabilidades legais, dano material, dano moral, dano estético e perda de uma chance. 2. ed. São Paulo: LTr, 2006. p. 13.
} 
Diante de tais percepções, o presente trabalho dedicou-se à compreensão do assédio moral como verdadeiro fenômeno, causado pela forma com que se operam as relações de poder dentro do contrato laboral, desde seu nascedouro até a completa deterioração. Para tanto, foram necessárias investigações históricas sobre o surgimento e a consolidação do poder na seara empresarial, e as conseqüentes condições ensejadoras da figura apresentada. De igual forma, foi preciso observar a forma com que o ordenamento jurídico pátrio vem tentando, desde a Constituição Federal de 1988, acompanhar esse processo.

Para afinar neste diapasão, o capítulo inaugural busca dar ênfase à proteção constitucional reservada ao trabalhador na Carta Política de 1988. São considerações gerais sobre o reconhecimento da importância do trabalho humano no ponto de vista econômico, político, ético, moral e social. Essa múltipla relevância leva à verificação de duas esferas protetivas distintas.

A primeira tutela a dignidade do trabalhador individualmente, levando em conta as necessidades existenciais de qualquer cidadão, que não podem sofrer temperamentos de acordo com o contexto inserido. A segunda se atém ao aspecto social do trabalho, e confere ao obreiro tutelas específicas, visando preservá-lo dentro pacto laboral.

Uma vez firmadas essas premissas, o estudo se encaminhou para a conceituação do contrato de trabalho e de sua forma mais complexa, o de emprego. A tutela diferenciada outrora exposta somente poderia ser efetivamente assimilada se reconhecidas as peculiaridades desta espécie de pacto.

A convergência da vontade de dois agentes capazes num ato formal que inaugura a relação produtiva é campo fecundo de desproporções e disparidades. No entanto, do ponto de vista jurídico, legitima, mesmo assim, o estado de sujeição do empregado diante do empregador. Com isso, buscou-se sublinhar a existência de poder dentro da relação empregatícia, o que faz do 
contrato verdadeiro instrumento de dominação. Ao empregador é dado controlar tudo o que se passa dentro da atividade empresarial, a fim de assegurar a ordem produtiva. Enquanto isso, do empregado, espera-se a correta e subserviente prestação de serviços.

É certo, porém, que o poder empresarial não pode ser tomado como absoluto e encontra óbices, quando não nos próprios termos contratuais, no ordenamento jurídico. A mola propulsora da relação de trabalho deve ser, incondicionalmente, a dignidade humana, e as garantias, individuais e sociais, do trabalhador.

O terceiro capítulo, por sua vez, analisará o assédio moral no contrato de trabalho a partir da inconteste possibilidade do poder se desviar do seu curso regular, que é a mantença da produtividade contratada. Tendo em vista a relativa novidade que a figura representa, foi preciso, antes, contextualizá-la, para, só então, adentrar na turbulenta zona de conceituação, identificação de agentes e condutas caracterizadoras.

Ao último capítulo, por fim, incumbiu a árdua missão de identificar a forma com que o assédio moral vem se firmando no cotidiano do judiciário trabalhista. Para a consecução desse fim, foi preciso repartir a investigação em dois momentos, distintos: os efeitos do assédio para o empregador e para o empregado.

Desprendeu-se, primeiro, uma busca legislativa, que foi, a bem da verdade, pouco próspera. Afinal, no Brasil, não há norma de alcance federal que cuide especificamente do tema, de modo que esforços em tal sentido já são verificados, através da existência de diversos projetos de lei em tramitação. Isso não significa, porém, total desamparo, já que a comunicação de dispositivos esparsos, na Constituição da República, na Consolidação das Leis do Trabalho e no Código de Processo Civil permite alguma resposta ao assédio moral. O dever de reparar o dano moral e a rescisão indireta do contrato são alguns exemplos desta. 
Ato contínuo, a pesquisa precisou enveredar pelo repositório jurisprudencial sobre assédio moral, que, embora parco em quantidade, é denso em seu conteúdo. Dentre as muitas novidades que despontam, recebe-se com euforia a consideração do assédio moral como acidente de trabalho, tendo em vista que seus efeitos sobre a saúde física e psíquica do trabalhador seriam reconhecidos como doença profissional.

Através dessa correta e fiel abordagem do assédio moral, em toda a sua complexa estrutura, abre-se uma importante via para a erradicação. O controle que se propõe parte da raiz do problema, privilegiando, assim, a honra e o trabalho digno. 


\section{Tutela constitucional do trabalhador}

\subsection{A dignidade da pessoa humana}

O Estado democrático brasileiro resguardou, como princípio fundamental enunciado na Carta Política de 1988, a dignidade da pessoa humana ${ }^{3}$, o que fez dela elemento central de todo o ordenamento ${ }^{4}$. Nem por isso deve-se quedar no erro de entender que a dignidade humana é uma criação constitucional. A bem da verdade, se esta foi assinalada como fundamento, precede ao próprio Estado, agindo muito mais como a mola propulsora da democracia, embora seja necessário reconhecer que estamos diante de um conceito jurídico indeterminado. Isto é, trata-se de uma expressão que não encontra seu conteúdo no ordenamento jurídico, mas que, nem por isso, fica à disposição discricionária dos aplicadores do direito. É que os conceitos jurídicos indeterminados admitem, sempre, uma única interpretação adequada, ou seja, trazem sempre uma só opção ao aplicador, afastadas quaisquer escolhas intermediárias.

A Declaração Universal dos Direitos do Homem e do Cidadão, aprovada pela Assembléia Constituinte da França de 1789 - na corrente de otimismo instaurada pela revolução - já nos confere um consistente norte na

\footnotetext{
${ }^{3}$ Art. $1^{\circ}$ A República Federativa do Brasil, formada pela união indissolúvel dos Estados e Municípios e do Distrito Federal, constitui-se em Estado Democrático de Direito e tem como fundamentos:

(...)

III - A dignidade da pessoa humana;

${ }^{4}$ De acordo com Arion Sayão Romita, “a dignidade da pessoa humana atua como princípio estruturante do Estado Democrático de Direito e, em conseqüência, impregna a totalidade de ordem jurídica, espraia-se por todos os ramos do direito positivo e inspira não só a atividade legislativa como também a atuação do Poder Judiciário". (ROMITA, Arion Sayão. Direitos Fundamentais na Relação de Trabalho. São Paulo: LTr, 2005. p. 251.)
} 
busca do conteúdo normativo da expressão em estudo. $\mathrm{O}$ artigo $1^{\circ}$ do louvável documento preceitua que “Os homens nascem e permanecem livres e iguais perante a lei; as distinções sociais não podem ser fundadas senão sobre a utilidade comum”.

A bem da verdade, a Carta de Direitos citada deu forma à obra de Immanuel Kant, datada de 1788. Em “Crítica da Razão Prática”, o filósofo reformula as bases da moralidade, em estreita atenção à correição dos atos humanos. São três os postulados formulados por Kant para guiar a conduta de tal modo que possa ser dita moral ${ }^{5}$ : i) “Age como se a máxima da tua ação devesse ser erigida por tua vontade em lei universal da natureza”; ii) “Age de tal maneira que sempre trates a humanidade tanto na tua pessoa como na pessoa de outrem, como um fim e nunca como um meio”; iii) “Age como se a máxima de tua ação devesse servir de lei universal para tos os seres racionais”.

Merece destaque o segundo corolário. Nele, Kant identifica o dever dos homens respeitarem a existência dos demais. Com isso, identifica um valor absoluto, inerente à qualidade de pessoa humana que o filósofo reconhece em todos os homens pelo simples fato de serem dotados de razão e que não precisa de outros fatores para que possa ser tutelado diante da coletividade. A filosofia kantiana, assim, condena qualquer prática que faça do homem instrumento para a consecução de outros objetivos. O valor dado à pessoa humana deve decorrer de um ato de moralidade pura, isto é, sem motivações externas, fundado apenas no reconhecimento da relevância intrínseca daquela prática ${ }^{6}$.

Por esta razão é que se pode afirmar que Kant inaugurou os pilares de sustentação dos direitos dos homens. Sua teoria tem o incontestável mérito de

\footnotetext{
${ }^{5}$ CHAUI, Marilena de Souza. Convite à Filosofia. 12. ed. São Paulo: Ática, 1999. pp. 444-445.

${ }^{6}$ Para a professora paulista Marilena Chaú, “a segunda máxima afirma a dignidade dos seres humanos como pessoas e, portanto, a exigência de que sejam tratados como fim da ação e jamais como meio ou como instrumento para nossos interesses". E tal como nas demais máximas, deve haver a interiorização do dever, uma vez que decorre da racionalidade humana, a qual permite que a vontade ponha a si mesmo sua lei. Essa perfeita adequação entre a vontade e o dever foi denominada por Kant de vontade boa. (Ibid. p. 445).
} 
indicar firmemente um caminho para o preenchimento do conceito jurídico de dignidade humana.

Por conseguinte, o preceito se repete na Declaração Universal dos Direitos Humanos, aprovada pela Organização das Nações Unidas em 1948, cujo artigo $1^{\circ}$ dita: “Todos os seres humanos nascem livres e iguais em dignidade e direitos. São dotados de razão e consciência e devem agir em relação uns aos outros com espírito de fraternidade”. Aqui, portanto, três importantes valores preenchem a noção de pessoa digna, a saber: liberdade, igualdade e fraternidade.

Aprofundando-se na questão, doutrina capitaneada pela professora Maria Celina Bodin de Moraes $^{7}$, ao investigar a expressão jurídica da dignidade da pessoa humana, procurou não lhe conferir abstração tal que faça dela a razão por trás de todo e qualquer direito, porque isto inviabilizaria sua concreta aplicação, ainda que seja esta uma tendência natural, já que a dignidade humana impregna hoje todos os setores da ordem jurídica. Então, buscando a essência que afasta os homens da condição de objeto, foi possível identificar quatro postulados básicos que conferem mais substância à noção de dignidade humana: igualdade, integridade psicofísica, liberdade e solidariedade.

Significa dizer que a dignidade humana depende do reconhecimento da existência de indivíduos iguais e que, como tal, fazem jus à mesma proteção de sua incolumidade moral e física, a ser respeitada ante seu direito de autodeterminação, isto é, de agir conforme sua própria vontade racional, sem que isto o prive da inserção e desenvolvimento em um grupo social ${ }^{8}$.

\footnotetext{
${ }^{7}$ BODIN de MORAES, Maria Celina. O Conceito de Dignidade Humana: Substrato Axiológico e Conteúdo Normativo. In: Ingo W. Sarlet. (Org.). Constituição, Direitos Fundamentais e Direito Privado. 2 ed. Porto Alegre: Livraria do Advogado Editora, 2006. p. 117.

${ }^{8}$ Fábio Konder Comparato destaca os mesmos corolários para compor a dignidade humana, na medida que "o ser humano passa a ser considerado, em sua igualdade essencial, como ser dotado de liberdade e razão, não obstante as múltiplas diferenças de sexo, raça, religião ou costumes sociais. Lançavam-se, assim, os fundamentos intelectuais para a compreensão da pessoa humana e para a afirmação da
} 
Diversos estados modernos, democráticos ou ao menos em processo de democratização constitucionalizaram a noção de dignidade humana. Senão, vejamos.

O constituinte italiano de 1947 define em seu artigo $3^{\circ}$ que "Todos os cidadãos têm a mesma dignidade social e são iguais perante a lei, sem discriminação de sexo, de raça, de língua, de religião, de opiniões políticas, de condições pessoais e sociais. Cabe à República remover os obstáculos de ordem social e econômica que limitando de fato a liberdade e a igualdade dos cidadãos, impedem o pleno desenvolvimento da pessoa humana e a efetiva participação de todos os trabalhadores na organização política, econômica e social do País”.

A Lei Fundamental de Bonn, como é conhecida a Carta Política alemã, aprovada pelo Conselho Parlamentar de 1949, mas que só foi admitida como Constituição Federal em 1990, traz logo em seu primeiro artigo a dignidade humana como um bem intangível cujo respeito e proteção é dever de todo Poder Público 9 .

A Constituição portuguesa de 1976, que veio por cobrir com uma pá de cal as cicatrizes deixadas pela ditadura de António Salazar, assim define a República de Portugal: “Artigo $1^{0}$ - Portugal é uma República soberana, baseada na dignidade da pessoa humana e na vontade popular e empenhada na construção de uma sociedade livre, justa e solidária”.

Como última ilustração, é preciosa a lembrança da moderna Carta de Direitos Fundamentais da União Européia, de 2000, cujo artigo primeiro diz: “A dignidade do ser humano é inviolável. Deve ser respeitada e protegida”.

existência de direitos universais, porque a ela inerentes”. (COMPARATO, Fábio Konder. A afirmação histórica dos Direitos Humanos. 3. ed. rev. e ampl. São Paulo: Saraiva, 2003. p. 11.)

${ }^{9}$ Artikel 1

[Menschenwürde - Menschenrechte - Rechtsverbindlichkeit der Grundrechte]

(1) Die Würde des Menschen ist unantastbar. Sie zu achten und zu schützen ist Verpflichtung aller staatlichen Gewalt. 
No entanto, o mero enunciar do relevo que a dignidade humana tem na construção de um estado democrático não é suficiente. Foi preciso mais, e por isso mesmo, a Constituição da República do Brasil estipulou também direitos, garantias e liberdades fundamentais que visam tutelar a existência humana em sociedade e seu desenvolvimento digno. Os setenta e oito incisos do artigo $5^{\circ}$ do Texto Magno são valores gravados pela inalienabilidade, imprescritibilidade e irrenunciabilidade, dentre os quais podemos citar a vida, liberdade, a igualdade, a propriedade, a não discriminação, a consciência, o trabalho, entre outros.

No entanto, os ditos direitos fundamentais não são apenas aqueles que constam sob tal título no texto político. É o que se extrai do parágrafo $2^{\circ}$ do artigo $5^{\circ}$, pelo qual “os direitos e garantias expressos nesta Constituição não excluem outros decorrentes do regime e dos princípios por ela adotados, ou dos tratados internacionais em que a República Federativa do Brasil seja parte”.

$\mathrm{O}$ excerto em comento demonstra um sistema aberto de direitos fundamentais, de modo que muitas outras garantias encontradas no texto constitucional poderão ser assim consideradas, na medida em que desdobram princípios consagrados na Constituição da República. E, suprimida qualquer destas garantias, temos, por via de conseqüência, a afronta à dignidade humana.

\subsection{Reverberações da dignidade humana nas relações de trabalho}

Quando a vigente Constituição da República foi promulgada, o então Deputado Ulysses Guimarães, na posição de Presidente da Assembléia Nacional Constituinte, a aclamou como o documento da liberdade, da dignidade, da democracia, da justiça social do Brasil. Em seu discurso, o notório parlamentar exaltou o papel do Texto Político de transformar “o 
homem em cidadão, e só é cidadão quem ganha justo e suficiente salário, lê e escreve, mora, tem hospital e remédio, lazer quando descansa”.

No inflamado e emocionado discurso, proferido no dia 05 de outubro de 1988, observa-se a preocupação do Constituinte Originário em resguardar um patamar uniforme de dignidade aos cidadãos, que servisse de mola propulsora no desenvolvimento do ideal de vida de cada um, como resultado inevitável do singelo e inequívoco fato de serem homens. Por conta disso que o extenso rol de direitos e garantias fundamentais representa limitação material ao poder reformador do Constituinte Derivado ${ }^{10}$.

Ocorre que, por muito tempo, foi recorrente o erro de afirmar que os direitos e garantias com amparo constitucional serviriam como proteção dos homens apenas ante aos atos emanados da Administração Pública. A contrário senso, assim, alguns deles poderiam ser postos de lado quando se tratasse de uma relação entre particulares.

Forçoso constatar que é um tanto quanto minimalista resumir o Estado como único obrigado pelos direitos fundamentais. Não se trata de negar que essa foi uma importante contribuição, principalmente diante dos traumas deixados por um período de violência institucionalizada pré Constituição de 1988. Mas é preciso ir além de somente impor ao Poder Público uma postura de abstenção no sentido de não violar os comandos impositivos emanados das prerrogativas fundamentais.

Não é tão somente a Administração Pública que pode agir no sentido de violar garantias existenciais dos cidadãos. Conforme Paulo Gustavo Gonet Branco, “outras forças sociais, como grupos econômicos ou políticos de peso,

\footnotetext{
${ }^{10}$ Cumpre sublinhar que embora o artigo $60, \S 4^{\circ}$ da CRFB faça menção em seu inciso IV apenas aos direitos fundamentais - transmitindo a errônea impressão de que apenas o artigo $5^{\circ}$ goza de imutabilidade ante ao Poder Derivado Reformador - a bem da verdade, todo o Título II do texto político deve ser interpretado como cláusula pétrea, sobretudo os direitos sociais. Isto porque o objetivo do constituinte originário ao obstar a abolição de certas regras constitucionais foi assegurar um núcleo mínimo de identidade da Constituição de 1988, de modo que não fosse dado ao constituinte reformador mutilar o texto político ao ponto de subverter -lhe a essência garantista. Logo, toda norma
} 
poderiam trazer para o indivíduo vários dos constrangimentos que se buscavam prevenir contra o Estado"11. Por esta razão, é um verdadeiro disparate a criação de uma dualidade de tratamento, na qual livra-se o homem das ingerências do Estado para, num segundo momento, abandoná-lo ao alvitre dos particulares, a quem seria dado tudo fazer, dispor e determinar, segundo vontades infundadas $^{12}$.

Nesse contexto, não se pode olvidar que os direitos fundamentais precisam também repercutir nas relações de direito privado. Diante de tal circunstância, o Poder Público assumiria um papel pró-ativo, interferindo sempre que necessário, para conferir efetividade às obrigações decorrente daqueles direitos aos quais a Constituição da República conferiu maiores garantias e proteções ${ }^{13}$. Conclui-se, portanto, pela notória existência de uma eficácia horizontal inerente aos direitos fundamentais, cuja relevância não é ofuscada pela posição soberana do Estado.

Levando em conta as bases sólidas do entendimento esmiuçado, a Constituição Portuguesa de 1976 deu a seguinte redação à primeira parte do seu artigo 18: “Os preceitos constitucionais respeitantes aos direitos, liberdades e garantias são directamente aplicáveis e vinculam as entidades públicas e privadas”.

No Brasil, a questão foi levada ao Supremo Tribunal Federal, com maior expressão, no ano de $2004^{14}$, em sede de Recurso Extraordinário, e

que se alinhe aos objetivos da Carta Cidadã deverá ser preservada íntegra, podendo ser objeto apenas de otimização, jamais de supressão.

${ }^{11}$ MENDES, Gilmar Ferreira et al. Curso de Direito Constitucional. 2 ed. São Paulo: Saraiva, 2008. p. 275.

${ }^{12} \mathrm{O}$ autor francês Jean Rivero, em obra clássica, sintetiza tal situação como "escapar da arbitrariedade do Estado para cair sob a dominação dos poderes privados”, o que, na verdade, seria apenas "mudar de servidão”. (RIVERO, Jean; FAVOREU, Louis. Tribunales constitucionales europeos y derechos fundamentales. Madrid: CEC, 1984. p. 673).

${ }^{13}$ Paulo Branco alça os direitos fundamentais ao posto de pilares da ordem jurídica e social, de modo que o Poder Público deve preservá-los e também promovê-los em todos os setores da sociedade civil. São, pois, princípios estruturantes da sociedade. (MENDES, Gilmar Ferreira et al. Op. cit. p. 275).

14 EMENTA: SOCIEDADE CIVIL SEM FINS LUCRATIVOS. UNIÃO BRASILEIRA DE COMPOSITORES. EXCLUSÃO DE SÓCIO SEM GARANTIA DA AMPLA DEFESA E DO CONTRADITÓRIO. EFICÁCIA DOSDIREITOS FUNDAMENTAIS NAS RELAÇÕES 
trouxe dissenso entre os Ministros. Embora tenha restado vencida, a ilustre Min. Elen Gracie militou no sentido de que entes privados gozam do atributo da auto-determinação, podendo se organizar e desenvolver seu relacionamento social de forma livre, desde que seus atos estejam agasalhados pela legislação civil vigente. Em que pese o brilhantismo da Ministra, o voto não pôde prosperar. Prevaleceu a decisão do atual Presidente do STF, Min Gilmar Mendes, para quem a eficácia horizontal dos direitos fundamentais é uma realidade inconteste. A posição vem foi defendida por ele em estudo específico sobre o tema:

PRIVADAS. RECURSO DESPROVIDO. I. EFICÁCIA DOS DIREITOS FUNDAMENTAIS NAS RELAÇÕES PRIVADAS. As violações a direitos fundamentais não ocorrem somente no âmbito das relações entre o cidadão e o Estado, mas igualmente nas relações travadas entre pessoas físicas e jurídicas de direito privado. Assim, os direitos fundamentais assegurados pela Constituição vinculam diretamente não apenas os poderes públicos, estando direcionados também à proteção dos particulares em face dos poderes privados. II. OS PRINCÍPIOS CONSTITUCIONAIS COMO LIMITES À AUTONOMIA PRIVADA DAS ASSOCIAÇÕES. A ordem jurídico-constitucional brasileira não conferiu a qualquer associação civil a possibilidade de agir à revelia dos princípios inscritos nas leis e, em especial, dos postulados que têm por fundamento direto o próprio texto da Constituição da República, notadamente em tema de proteção às liberdades e garantiasfundamentais. $\mathrm{O}$ espaço de autonomia privada garantido pela Constituição às associações não está imune à incidência dos princípios constitucionais que asseguram o respeito aosdireitos fundamentais de seus associados. A autonomia privada, que encontra claras limitações de ordem jurídica, não pode ser exercida em detrimento ou com desrespeito aosdireitos e garantias de terceiros, especialmente aqueles positivados em sede constitucional, pois a autonomia da vontade não confere aos particulares, no domínio de sua incidência e atuação, o poder de transgredir ou de ignorar as restrições postas e definidas pela própria Constituição, cuja eficácia e força normativa também se impõem, aos particulares, no âmbito de suas relações privadas, em tema de liberdadesfundamentais. III. SOCIEDADE CIVIL SEM FINS LUCR ATIVOS. ENTIDADE QUE INTEGRA ESPAÇO PÚBLICO, AINDA QUE NÃO-ESTATAL. ATIVIDADE DE CARÁTER PÚBLICO. EXCLUSÃO DE SÓCIO SEM GARANTIA DO DEVIDO PROCESSO LEGAL.APLICAÇÃO DIRETA DOS DIREITOS FUNDAMENTAIS À AMPLA DEFESA E AO CONTRADITÓRIO. As associações privadas que exercem função predominante em determinado âmbito econômico e/ou social, mantendo seus associados em relações de dependência econômica e/ou social, integram o que se pode denominar de espaço público, ainda que não-estatal. A União Brasileira de Compositores - UBC, sociedade civil sem fins lucrativos, integra a estrutura do ECAD e, portanto, assume posição privilegiada para determinar a extensão do gozo e fruição dosdireitos autorais de seus associados. A exclusão de sócio do quadro social da UBC, sem qualquer garantia de ampla defesa, do contraditório, ou do devido processo constitucional, onera consideravelmente o recorrido, o qual fica impossibilitado de perceber os direitosautorais relativos à execução de suas obras. A vedação das garantias constitucionais do devido processo legal acaba por restringir a própria liberdade de exercício profissional do sócio. O caráter público da atividade exercida pela sociedade e a dependência do vínculo associativo para o exercício profissional de seus sócios legitimam, no caso concreto, a aplicação direta dos direitos fundamentais concernentes ao devido processo legal, ao contraditório e à ampla defesa (art. 5, LIV e LV, CF/88). IV. RECURSO EXTRAORDINÁRIO DESPROVIDO.

(STF, RE 201819/ RJ, Rel. Min. Ellen Gracie, Brasília, 11 out. 2005.) 
Um entendimento segundo o qual os direitos fundamentais atuam de forma unilateral na relação entre cidadão e o Estado acaba por legitimar a idéia de que haveria para o cidadão sempre um espaço livre de qualquer ingerência estatal. A adoção dessa orientação suscitaria problemas de difícil solução tanto no plano teórico, como no plano prático. O próprio campo do Direito Civil está prenhe de conflitos de interesses com repercussão no âmbito dos direitos fundamentais. O benefício concedido a um cidadão configura, não raras vezes, a imposição de restrição a outrem ${ }^{15}$.

É bem verdade que a autonomia da vontade, embora não esteja expressa na Constituição Federal, deve ser vista como princípio constitucional. Trata-se de conclusão inconteste, que chega da leitura do artigo $5^{\circ}$, caput - onde está consagrado um direito a liberdade em linhas gerais - associado ao inciso III do artigo $1^{\circ}$, que enuncia a dignidade humana como princípio. Ora, como dito nas laudas anteriores, a dignidade da pessoa humana, para poder ser conceituada, precisa ser desdobrada em quatro corolários, dentre os quais encontramos a liberdade de autodeterminação. Neste tom, a Constituição de 1988 consagrou o direito do indivíduo agir com autonomia na gestão da sua vida privada, e, portanto, consolidou a liberdade de contratar.

Todavia, não se poder reduzir tal conclusão a termos absolutos. Serão constantes os embates entre direitos fundamentais e a autonomia da vontade dos indivíduos, sendo essencial a aplicação de uma técnica de ponderação. A concordância prática torna-se mais fácil quando a situação fática versar em torno de pessoas materialmente equiparadas. Por outro lado, quando se estiver diante de relações especiais de sujeição, em que uma das partes é gravado por um estado atípico de inferioridade, o controle há de ser mais rígido, para afastar excessos que atentem contra o mínimo de existência digna deste sujeito.

Exemplo mais fiel dessa situação especial narrada é a relação de trabalho. Como será visto de maneira mais detida no próximo capítulo, o contrato de trabalho é instrumento de legitimação de uma sujeição que não é voluntária, mas, na verdade, necessária para que o trabalhador não padeça do

\footnotetext{
${ }^{15}$ MENDES, Gilmar Ferreira. Direitos fundamentais e controle de constitucionalidade: estudos de direito constitucional. 2. ed. rev. e ampl. São Paulo: Instituto Brasileiro de Direito Constitucional, 1999. p. 218.
} 
estado de mais absoluta miséria. Em tal cenário, os direitos fundamentais surgem como asseguradores de um mínimo ético indispensável para a preservação da ordem jurídica e moral dentro daquela peculiar relação. Isto é, embora não se tratem de direitos exclusivos do trabalhador, ganham especial relevo dentro da relação de trabalho, onde as lesões aos direitos fundamentais são mais freqüentes, e já não causam tamanha perplexidade.

Na autorizada doutrina do professor Arion Sayão Romita ${ }^{16}$, dentro do contrato de trabalho, ganham singular relevo os seguintes direitos fundamentais: (i) igualdade, (ii) intimidade, (iii) vida privada, (iv) honra, (v) imagem e (vi) livre manifestação de pensamento, crença, expressão e informação.

Sendo tais valores precípuos também consagrados na Constituição Portuguesa $^{17}$, o moderno Código do Trabalho daquele país, de 27 de agosto de 2003, tratou de, em seu próprio corpo, aplicar direitos fundamentais constitucionalizados a hipóteses concretas. Não deixar a cargo apenas da doutrina e da jurisprudência o enfrentamento de circunstâncias fáticas - como ocorre no nosso ordenamento jurídico - foi uma opção legislativa bastante eficaz, ainda mais se considerado que as previsões do código em comento não têm a pretensão de esgotar a matéria. Isto é, nada impede que novos casos concretos ensejem nova ponderação entre direitos fundamentais e autonomia privada, o que caberia ao aplicador do direito.

\footnotetext{
${ }^{16}$ ROMITA, Arion Sayão. Op. cit. p. 323.

${ }^{17}$ Os artigos que inauguram o capítulo de direitos, liberdades e garantias pessoais, do Texto Político português promulgado em 1976, dedicam especial atenção ao direito à vida, à integridade pessoal, à liberdade e segurança (artigo 24, 25 e 27 respectivamente). Um rol mais extenso consta do artigo 26, que conta com a seguinte redação:

“1. A todos são reconhecidos os direitos à identidade pessoal, ao desenvolvimento da personalidade, à capacidade civil, à cidadania, ao bom nome e reputação, à imagem, à palavra, à reserva da intimidade da vida privada e familiar e à proteção legal contra quaisquer formas de discriminação.

2. A lei estabelecerá garantias efetivas contra a obtenção e utilização abusivas, ou contrárias à dignidade humana, de informações relativas às pessoas e famílias.

3. A lei garantirá a dignidade pessoal e a identidade genética do ser humano, nomeadamente na criação, desenvolvimento e utilização das tecnologias e na experimentação científica.

4. A privação da cidadania e as restrições à capacidade civil só podem efetuar-se nos casos e termos previstos na lei, não podendo ter como fundamento motivos políticos”.
} 


\subsubsection{Proibição de discriminar e liberdade de expressão e opinião do trabalhador}

Na relação de trabalho, o direito fundamental à igualdade traduz-se na proibição de discriminar, isto é, de valer-se de peculiares do trabalhador para lhe subtrair oportunidades, diferenciar tratamento e subverter resultados do contratado, ainda que, em fases de tratativa.

A conduta que se busca desarraigar apresenta dois momentos distintos. Num primeiro, há uma animosidade do contratante contra certa característica inerente a um trabalhador. Esta característica pode ser de ordem física, social, cultural, quiçá quanto a opções de foro íntimo. Elementos que, na praxe, se tornaram estopim de diversos atos de exclusão são, por exemplo, aparência física, idade, sexo, orientação sexual, estado civil, situação familiar, patrimônio genético, capacidade de trabalho reduzida, deficiência ou doença crônica, nacionalidade, origem étnica, religião, convicções políticas ou ideológicas e filiação sindical. No segundo momento, verifica-se a efetivação de um ato de segregação contra aquele que ostente tais características.

A liberdade é protegida no texto político de 1988 no caput artigo $5^{\circ}$ de forma genérica, e, de maneira mais pormenorizada, em diversos incisos, como, à guisa de ilustração, IV, assegurando liberdade de pensamento, VI, acerca de liberdade religiosa, IX sobre a liberdade expressão, XVII, quanto à liberdade de associação. Da leitura dos dispositivos citados, verifica-se que o individuo é cercado por direitos e garantias que pretendem impedir que sua atuação e desenvolvimento em sociedade sejam mitigados por imposições de terceiros. Ora, se a Carta Magna assegura aos indivíduos o direito de fazer suas próprias opções, e mais, de ostentá-las publicamente, é forçoso vedar também que estes venham a ser discriminados por conta de tais escolhas. 
Cumpre sublinhar que os atos discriminatórios - idôneos para ensejar responsabilidade trabalhista -, podem ocorrer não só na vigência do pacto laboral, como quando a distinção injuriosa enseja a despedida do trabalhador ou repercute no tratamento que lhe é dispensado, mas também nas fases pré e pós contratual. Em qualquer desses três momentos, advindo uma conduta do contratante no sentido de preterir certo trabalhador e, conseqüentemente, mitigar a igualdade formal, é notoriamente inconstitucional, provoca lesão à direito fundamental e precisa ser combatida com rigor.

É preciso acautelar-se de não tornar a vedação de atos discriminatórios uma maneira de ultrapassar os limites da autonomia privada. Guilherme Machado Dray ${ }^{18}$ lembra que é inegável que o contratante tem liberdade para optar por um trabalhador, como fruto do seu direito de gerir autonomamente o empreendimento cujos riscos são só seus. $\mathrm{Na}$ mesma medida, tem o empregador o direito de demitir um empregado sem justa causa. Tratam-se de decorrências legítimas da natureza intuito personae do contrato de trabalho. Por essas razões, não se pode tachar como discriminação quaisquer requisitos exigidos, pois, muitas vezes, dizem respeito às minúcias da atividade que será exercida ou o contexto de sua execução, desde que a condição imposta seja razoável e proporcional. O que se procura repelir é que tais condutas que de fato estão ao alcance do empregador ultrapassem os limites do exercício regular do seu direito, quando pautada em ímpetos meramente discriminatórios.

Na Constituição Federal de 1988, o artigo $7^{\circ}$, em duas ocasiões distintas, trouxe a regra da vedação da discriminação como garantias do trabalhador. O inciso XXX do precitado artigo dita a "proibição de diferença de salários, de exercício de funções e de critério de admissão por motivo de sexo, idade, cor ou estado civil”. O inciso seguinte, por sua vez, veda qualquer “discriminação

\footnotetext{
${ }^{18}$ DRAY, Guilherme Machado. O princípio da igualdade no direito do trabalho. Coimbra: Almedina, 1999. p. 345 .
} 
no tocante a salário e critérios de admissão do trabalhador portador de deficiência”.

Ocorre que determinadas situações, embora pudessem ser resolvidas apenas no âmbito da regra geral esculpida pelas normas constitucionais, mereceram regramento mais específico, em face da freqüência das lesões a que davam azo. É o caso clássico do trabalho feminino. A Consolidação Trabalhista reconhece, e não poderia ser diferente, que a estrutura física da mulher lhe coloca em certa disparidade de armas com o trabalhador masculino, e não seria razoável exigir-lhe o exercício de certas atividades ${ }^{19}$. Logo, a exclusão do trabalhador de sexo feminino de certas atividades tem até mesmo amparo legal e jamais poderia ser considerado ato discriminatório.

No entanto, a prática trabalhista revelou uma série de outras distinções aplicadas pelo empregador na gestão do trabalho feminino. Foi nessa disposição de espírito que foram inauguradas as leis $n^{\circ} 9.029$, de 13 de abril de 1995, e a lei 9.799 de 26 de maio de 1999, que criminalizaram atos discriminatórios contra a trabalhadora. A guisa de exemplo, a exigência de qualquer comprovante de gestação ou esterilidade, bem como a rescisão do contrato de trabalho em virtude do estado gravídico, e a divulgação de oferta de emprego exigindo determinado sexo sem justo motivo passaram a ser crime punido com detenção, cumulada com multa administrativa. As novas regras foram introduzidas no texto celetista através do artigo 373-A.

Os portadores de deficiência, historicamente marginalizados da sociedade, também necessitaram de amparo legislativo especial para se assegurarem no mercado de trabalho gozando de igualdade de tratamento ante aos demais trabalhadores, sem, porém, que suas necessidades especiais sejam ignoradas. Para tanto, a lei $n^{\circ} 8.213$ /91 estipulou a reserva de vagas e cargos a

\footnotetext{
${ }^{19}$ Art. 390. Ao empregador é vedado empregar a mulher em serviço que demande o emprego de força muscular superior a vinte quilos para o trabalho contínuo, ou vinte e cinco quilos para o trabalho ocasional.
} 
deficientes físicos nos quadros de empreendimentos que contem com mais de 100 empregados $^{20}$.

A lei em tela representa uma prática de discriminação, no entanto do tipo positiva. Isto é, ao considerar as reais situações de certos trabalhadores, lançou-se mão de uma série de políticas de inclusão, voltadas para a otimização das oportunidades oferecidas às pessoas em condições peculiares. Algumas medidas discriminatórias positivas foram constitucionalizadas, como esta, de proteção ao trabalhador deficiente, prevista no artigo $7^{\circ}$ inciso VIII, ou ainda a proteção ao mercado de trabalho feminino através de incentivos específicos, nos termos inciso XX do mesmo artigo.

\subsubsection{Respeito à intimidade e vida privada do trabalhador}

A Constituição Federal reservou ao indivíduo, como um direito fundamental, certa esfera de atuação livre de quaisquer ingerências, seja de terceiros ou do próprio Estado, que é a intimidade e vida privada. Trata-se de uma zona particular que o indivíduo pode resguardar da participação da coletividade, mantendo-a fora do conhecimento desta.

Alice Monteiro de Barros $^{21}$ assim justifica os objetivos da Constituição Federal ao proteger o direito à intimidade dos cidadãos no inciso $\mathrm{X}$ do artigo 5": “visa a resguardar as pessoas dos sentidos alheios, principalmente da vista e

Parágrafo único. Não está compreendida na determinação deste artigo a remoção de material feita por impulsão ou tração de vagonetes sobre trilhos, de carros de mão ou quaisquer aparelhos mecânicos.

${ }^{20}$ Segundo nota do professor Amauri Mascaro Nascimento, Dinamarca, Suécia, Finlândia, EUA, Canadá, Nova Zelândia e Austrália já repudiaram o sistema de cotas para deficientes físicos no mercado de trabalho, alegando que a citada reserva seria, por si só, ato discriminatório que ressalta a inferioridade técnica destes. O argumento, embora sedutor, é falacioso, carregado da utopia de ser possível vislumbrar uma igualdade material entre deficientes e pessoas em pleno gozo de suas funções físicas. (NASCIMENTO, Amauri Mascaro. Curso de direito do trabalho. 22. ed. rev. e atual. São Paulo: Saraiva, 2007. p. 511). Mais especificamente, os EUA optaram pelo sistema da reabilitação, em que se exigem melhores acomodações do ambiente de trabalho para assegurar paridade de armas entre deficientes e não deficientes na execução das atividades laborativas.

${ }^{21}$ BARROS, Alice Monteiro. Proteção à intimidade do empregado. São Paulo: LTr, 1997. p. 28. 
dos ouvidos de outrem; pressupõe ingerência na esfera íntima da pessoa através de espionagem e divulgação de fatos íntimos obtidos ilicitamente”.

Aplicando estas linhas teóricas à relação de emprego, verifica-se que existe um claro dever de abstenção do contratante, traduzido na impossibilidade de perseguir o acesso à esfera privada do trabalhador. Em outras palavras, o trabalhador não pode ser compelido a levar ao alcance do empregador aspectos de foro íntimo, estejam eles no plano psicológico ou físico, nem sequer acatar as ordens deste no que tange a forma com que dirige sua vida fora âmbito profissional. A única exceção que se pode admitir ocorre quando tais dados da vida privada do trabalhador sejam estritamente e relevantes para avaliar a respectiva aptidão à execução do contrato de trabalho. Portanto, continua a professora Alice Monteiro de Barros, o contrato de trabalho não pode se tornar um "título legitimador de recordes no exercício de direitos fundamentais”.

É preciso sublinhar que o poder de comando que socorre ao empregador - e que será objeto de melhor estudo no capítulo seguinte -, se justifica pela assunção de riscos do empreendimento, que é exclusivamente sua. Se todos os resultados do empreendimento - ganhos ou perdas -, serão arcados pelo empregador, é justo que ele possa controlar a forma com que seus subordinados estão desenvolvendo aquela atividade, no sentido de reduzir riscos e otimizar lucros. O mesmo fundamento, porém, não socorre os resultados que questões pessoais do trabalhador podem trazer. Estas reverberam apenas na vida privada do empregado, e por isso não podem ser objeto de interferência do empregador.

A distinção entre a subordinação jurídica do trabalhador ao seu empregador e uma arbitrária submissão pessoal foi objeto de estudo do professor Arion Romita ${ }^{22}$. Para ele, a relação jurídica que nasce do contrato de

\footnotetext{
${ }^{22}$ ROMITA, Arion Sayão. A subordinação no contrato de trabalho. Rio de Janeiro: Forense, 1979. p. 32.
} 
trabalho incide tão somente na atividade profissional, sendo esta inconfundível com a pessoa do trabalhador.

No direito comparado, chama a atenção a cautela com que o Código do Trabalho português abordou o tema do direito à intimidade. $\mathrm{O}$ artigo 16 do diploma citado dispõe que “o empregador e o trabalhador devem respeitar os direitos de personalidade da contraparte, cabendo-lhes, designadamente, guardar reserva quanto à intimidade da vida privada”. E segue na alínea seguinte: “O direito à reserva da intimidade da vida privada abrange quer o acesso, quer a divulgação de aspectos atinentes à esfera íntima e pessoal das partes, nomeadamente relacionados com a vida familiar, afectiva e sexual, com o estado de saúde e com as convicções políticas e religiosas”. Ainda em claro reconhecimento de que o contrato de trabalho não anula a autonomia, liberdade e privacidade do trabalhador, o artigo 20 veda que o empregador se valha de equipamentos tecnológicos de vigilância de longo alcance no ambiente de trabalho, para que isto não sirva de forma de controle do desempenho profissional e coação.

Por seu turno, a jurisprudência brasileira já se deparou com complexos embates entre o poder diretivo do empregador e a privacidade do empregado. Diversas práticas usualmente adotadas como meio de controle do empreendimento já foram apontadas como lesivas de direitos. Ganhou destaque especial no meio jurídico a questão da fiscalização de correspondência trocada por empregados em endereços do domínio eletrônico do empregador.

Grandes corporações, hodiernamente, disponibilizam aos seus empregados endereços eletrônicos funcionais, gerenciados pelo sistema de comunicação em rede da empresa. O acesso, pelo empregador, aos registros das correspondências enviadas e recebidas por meio destes endereços tornou-se recorrente, sob a justificativa de que seria uma forma de assegurar a 
produtividade e, até mesmo, resguardar informações sigilosas acerca do empreendimento $^{23}$.

Já decidiu o egrégio $\mathrm{TST}^{24}$ que é lícita a incursão do empregador no endereço eletrônico funcional que disponibiliza aos seus empregados. Tratando-se de ferramenta de trabalho fornecida pela empresa, está sob seu domínio, e, sabendo o trabalhador disso, ao fazer circular ali informações pessoais, está abdicando de seu direito de intimidade.

Seguindo a linha das grandes polêmicas que o direito à privacidade do trabalhador já suscitou, é indispensável analisar a questão da revista íntima. A intervenção visual nos pertences e, muitas vezes, no corpo do trabalhador para certificar-se que este não está se locupletando de bens utilizados no empreendimento é defendido como um meio de proteção do patrimônio do empregador. Isto é, uma forma de dirigir seu empreendimento no sentido de minimizar prejuízos.

\footnotetext{
${ }^{23}$ Favorável ao controle da correspondência eletrônica do trabalhador no ambiente de trabalho, Alexandre Agra Belmonte entende que é dado ao empregador desenvolver "meios de segurança do sistema e do controle formal contra a disseminação de vírus e também para evitar fraudes, concorrência desleal, violação de segredos”. (BELMONTE, Alexandre Agra. O monitoramento da correspondência eletrônica nas relações de trabalho. São Paulo: LTr, 2004, p. 85).

${ }^{24}$ A) RECURSO DE REVISTA OBREIRO: I) DANO MORAL - NÃO CARACTERIZAÇÃO ACESSO DO EMPREGADOR ACORREIO ELETRÔNICO CORPORATIVO - LIMITE DA GARANTIA DO ART. 5, XII, DA CF. 1. O art. $5^{\circ}$, XII, da CF garante, entre outras, a inviolabilidade do sigilo da correspondência e da comunicação de dados. 2. A natureza da correspondência e da comunicação de dados é elemento que matiza e limita a garantia constitucional, em face da finalidade da norma: preservar o sigilo da correspondência - manuscrita, impressa ou eletrônica - da pessoa física ou jurídica - diante de terceiros. 3. Ora, se o meio de comunicação é o institucional - da pessoa jurídica -, não há de se falar em violação do sigilo de correspondência, seja impressa ou eletrônica, pela própria empresa, uma vez que, em princípio, o conteúdo deve ou pode ser conhecido por ela. 4. Assim, se o -e-mail- é fornecido pela empresa, como instrumento de trabalho, não há impedimento a que a empresa a ele tenha acesso, para verificar se está sendo utilizado adequadamente. Em geral, se o uso, ainda que para fins particulares, não extrapola os limites da moral e da razoabilidade, o normal será que não haja investigação sobre o conteúdo de correspondência particular em -e-mailcorporativo. Se o trabalhador quiser sigilo garantido, nada mais fácil do que criar seu endereço eletrônico pessoal, de forma gratuita, como se dá com o sistema -gmail- do Google, de acesso universal. 5. Portanto, não há dano moral a ser indenizado, em se tratando de verificação, por parte da empresa, do conteúdo do correio eletrônico do empregado, quando corporativo, havendo suspeita de divulgação de material pornográfico, como no caso dos autos. (TST, RR - 9961/2004-015-09-00.1, Rel. Ives Gandra Martins Filho, Brasília, 18 fev 2009). No mesmo sentido: TST, AIRR-1.542/2005055-02-40.4, Rel. Ives Gandra, Brasília, 06 de jun 2008).
} 
No entanto, como bem assinala a professora Alice Barros ${ }^{25}$, tais prerrogativas do empregador encontram óbice na razoabilidade e na proporcionalidade. A revista não será razoável quando não houver risco concreto ao patrimônio do empregador, já que é da natureza do contrato a presunção de fidúcia entre este e o empregado. Da mesma forma, é descabida se existirem outros meios, menos invasivos, de realizar a fiscalização, como instalação de alarmes magnéticos nos bens da empresa, que sinalizam quando retirados do estabelecimento, ou de câmeras de vigilância nas áreas comuns. Será, por outro lado, desproporcional quando investiga mais espaços do que aqueles em que efetivamente poderia ocorrer a ocultação ou quando não há acordo para tanto, vez que o empregador não tem o poder de polícia necessário para obrigar o trabalhador a abdicar de direitos fundamentais.

A jurisprudência caminha divergente sobre o tema. No âmbito do Tribunal Superior do Trabalho, encontram-se decisões que, por um lado, admitem a revista ao trabalhador desde que pautada na proporcionalidade ${ }^{26}$, e,

${ }^{25}$ BARROS, Alice Monteiro. Op. cit. p. 74.

26 RECURSO DE REVISTA. DANOS MORAIS. REVISTA ÍNTIMA E DE BOLSA DE EMPREGADO. EMPRESA DE GÊNEROS ALIMENTÍCIOS. PRODUTOS COM POUCO VOLUME. DEFESA DO PATRIMÔNIO. Emerge do quadro fático delineado pelo v. acórdão recorrido que a revista era realizada com moderação e razoabilidade. E que, em momento algum, houve constrangimento e humilhação na realização destas. Sendo assim, as revistas da maneira como eram realizadas não caracterizam abuso de direito ou ato ilícito, constituindo, de fato, exercício regular do direito do empregador, inerente ao seu poder diretivo e de fiscalização. Nessa esteira, a revista em bolsas, sacolas ou mochilas dos empregados, sem que se proceda à revista íntima e sem contato corporal, mas apenas visual e em caráter geral relativamente aos empregados de mesmo nível hierárquico, não caracteriza excesso por parte do empregador, inabilitando o autor à percepção da indenização por danos morais. Recurso de revista conhecido e não provido. (TST, RR - 12165/2003008-09-00.7, Rel. Horácio Raymundo de Senna Pires, Brasília, 26 ago. 2009).

No mesmo sentido: RECURSO DE REVISTA. SALÁRIO -IN NATURA-. AUXÍLIOALIMENTAÇÃO. DESCONTO. PROVIMENTO. A não-gratuidade na alimentação fornecida pela empresa descaracteriza a natureza salarial da verba. No presente caso, restou consignado pelo Eg. Tribunal Regional que era efetuado desconto mensal no salário do reclamante a título de auxílioalimentação. Recurso conhecido e provido. DANO MORAL. REVISTA VISUAL. INEXISTÊNCIA. Restou delimitado no v. acórdão regional que a revista em bolsa dos empregados se dava sem contato físico e sem exposição dos empregados. Assim, a revista não constitui por si só, motivo a provar o constrangimento, nem violação da intimidade da pessoa, razão por que indevida a indenização por dano moral. Recurso de Revista conhecido e provido no tema. DANO MORAL. HUMILHAÇÃO. DESPEDIDA INJUSTA. ÔNUS DA PROVA. MATÉRIA FÁTICA. Não se conhecer do recurso de revista, quando o que se pretende é reexame de matéria fático-probatória. Óbice da Súmula 126 do C. TST. (TST, RR - 1455/2004-005-09-00.7, Rel. Aloysio Corrêa da Veiga, Brasília, 05 ago 2009). 
de outro, decisões que entendem que nenhuma circunstância autoriza a incursão do empregador no corpo ou pertences do empregado ${ }^{27}$.

\subsubsection{Preservação da honra e imagem do trabalhador}

A honra de uma pessoa é desdobramento natural de sua condição de pessoa humana e se desenvolve em dois aspectos distintos. No primeiro, de cunho subjetivo, a honra é o sentimento que um indivíduo tem a respeito dele próprio, suas convicções pessoas e caráter que utiliza nas suas relações interpessoais. Trata-se de uma perspectiva situada no plano da consciência individual de cada um.

Num segundo momento, a honra é inerente a toda pessoa inserida numa coletividade e significa o conjunto de valores que extravasa sua esfera íntima e impregna o conceito que os outros têm dela. Em uma única palavra, trata-se da

27 I - RECURSO DE REVISTA DO RECLAMANTE. 1. DANO MORAL. REVISTA ÍNTIMA. CONFIGURAÇÃO. 1.1. A CLT consagra o poder diretivo do empregador (art. $2^{\circ}$ ), que se manifesta por meio do controle, vigilância e fiscalização dos seus empregados. Tal poder encontra limites também legalmente traçados. Ninguém pode tudo. Os poderes de qualquer indivíduo, de qualquer instituição, para além do que trace o ordenamento, estão limitados não só pelo que podem os outros indivíduos e instituições, mas, ainda, pelo que, legitimamente, podem exigir na defesa de seus patrimônios jurídicos. 1.2. A Constituição da República (arts. $1^{\circ}$, inciso III, e $5^{\circ}$, -caput- e incisos III e X) tutela a privacidade e a honra, coibindo práticas que ofendam a dignidade da pessoa humana e constituam tratamento degradante. O art. 373-A, inciso VI, da CLT, por seu turno, traz vedação expressa à revista íntima - embora dirigido às mulheres empregadas, é passível de aplicação aos empregados em geral, em face do princípio da igualdade também assegurado pelo Texto Maior. 1.3. Ao assumir os riscos de seu empreendimento (CLT, art. $2^{\circ}$ ), o empregador toma a si a obrigação de adotar providências que garantam a segurança de seu patrimônio, iniciativa que encontrará larga resposta por parte da tecnologia moderna. 1.4. Não há nada e nenhuma norma que autorize o empregador ou seus prepostos a obrigar empregados ao desnudamento para revistas. 1.5. Não há revista íntima razoável. $\mathrm{O}$ ato em si constitui abuso de direito e, diante do regramento constitucional, é ilícito. O direito de propriedade não se estende a ponto de permitir ao empregador dispor da intimidade de seus empregados, submetendo-os, cruelmente, a humilhações, às quais se curvam pela necessidade de conservação do emprego. Não é razoável tolerar-se a recusa a valor tão básico, cuja reiteração, por certo, redunda em rigorosa modificação do espírito e em irrecusável sofrimento para o trabalhador. 1.6. Pergunta-se como reagiriam empregador, seus prepostos e, ainda, aqueles que sustentam tal comportamento, acaso submetidos a diárias revistas íntimas. Não se crê que, então, sustentassem-nas com tal vigor. 1.7. São inapreensíveis por outrem os direitos pessoais à preservação da dignidade, intimidade, privacidade e honra. 1.8. Infligindo dano moral, obriga-se o empregador à indenização correspondente (CF, art. 5, V). Recurso de revista conhecido e provido. (TST, RR - 960/2005-011-03-00.0, Rel. Alberto Luiz Bresciani de Fontan Pereira, Brasília, 24 jun 2009). 
reputação do indivíduo, e que, uma vez afrontada, provoca constrangimento e humilhação.

A imagem é indissociável da pessoa. Todos nós gozamos de uma imagem, isto é, uma percepção que se tem de nós, podendo ser ela meramente visual ou valorativa. É vedado ao empregador fazer uso da primeira, bem como macular a segunda, pois são constitucionalmente protegidas, nos termos do inciso $\mathrm{X}$ do artigo $5^{\circ}$ da CRFB.

Em que pese a clareza com que a Constituição da República resguardou tais atributos da dignidade humana, são corriqueiras as condutas patronais no sentido de violar o direito à imagem e a honra do trabalhador. A veiculação da imagem do empregado visando vantagem econômica, por exemplo, pode trazer ao mesmo uma exposição constrangedora.

Mais grave ainda é o caso da divulgação de dados, falsos ou não, que podem vir a comprometer o conceito que a sociedade mantém sobre o trabalhador. A formação de listas negras cumpre esse potencial lesivo, que não se limita ao campo extrapatrimonial, como valor abstrato, podendo até mesmo repercutir na economia do trabalhador, haja vista as propostas de trabalho que podem jamais evoluir das tratativas devido ao que foi divulgado sobre o obreiro. Tais listagens relacionam os dados pessoais dos empregados que acionaram seus empregadores judicialmente no pleito dos direitos mitigados no momento da rescisão do contrato de trabalho. Foi para evitar esse tipo de repercussão negativa do exercício do direito de acesso à justiça que louvável iniciativa do TST proibiu a divulgação, no sistema de consulta processual, do nome do obreiro que ajuizou reclamatória trabalhista.

A Carteira de Trabalho e Previdência Social também tem sido manuseada pelos empregadores como forma de denegrir a imagem do trabalhador, a partir da redação, no documento, de informações tão negativas quanto desnecessárias. A Consolidação das Leis Trabalhistas já procurou impedir esse mau uso da CTPS, no artigo 29, $\S 4^{\circ}$. 
Recentemente, chamou a atenção da mídia a condenação de uma grande instituição financeira, já transitada em julgado, na reparação dos danos morais causados a funcionário que, ao não cumprir metas fixadas previamente, era submetido a uma série de situações vexatórias. Sob a afrontosa denominação de "jogos motivacionais", a direção do banco obrigava o funcionário supostamente ineficaz, na presença de todos os seus pares, a usar fantasia de burro, fazer danças obscenas e executar trabalhos alheios a sua esfera de competência. Nada mais lesivo à reputação e boa fama que aquele funcionário empenhava-se em cultivar na sua vida social ${ }^{28}$.

\subsection{Garantias específicas do trabalhador}

A dignidade humana traz um núcleo essencial de direitos que, inevitavelmente, precisa ser desdobrado na medida em que são reconhecidas especificidades inerentes de determinados grupos de indivíduos. Essa progressividade na proteção do homem deu origem às gerações, ou dimensões, de direitos consagrados na Constituição Federal de 1988. Trata-se da verificação de que garantias genéricas não são plenamente eficazes diante das disparidades da realidade humana.

Os direitos individuais, que correspondem aos de primeira dimensão, previstos no artigo $5^{\circ}$ da CRFB, exprimem proteção de valores naturais, partindo da certeza de que a sociedade é composta por homens livres e iguais. Por via de conseqüência, os direitos sociais são, então, introduzidos como mecanismo de concretização dessa pretensa igualdade, no artigo $6^{\circ}$ da CRFB.

Na lição do saudoso constitucionalista José Afonso da Silva ${ }^{29}$, os direitos sociais podem ser conceituados como prestações positivas,

\footnotetext{
${ }^{28}$ Cf. TRT18, RO 00653-2006-004-18-00-0, Rel. Marilda Jungman G. Daher, Goiás, 17 out 2007 e TST, AIRR 653/2006-004-18-40, Rel. Min. Walmir Oliveira da Costa, Brasília, 04 fev 2009.

${ }^{29}$ SILVA, José Afonso. Curso de direito constitucional positivo. 24. ed. São Paulo: Malheiros, 2004. p. 286.
} 
proporcionadas pelo Estado, que visam assegurar aos hipossuficientes melhores condições de vida, na medida em que atenuam desigualdades sociais.

Em que pese a distinção entre direitos individuais e direitos sociais, certo é que ambos estão acobertados pelo rótulo de direitos fundamentais, ou seja, cada qual corresponde a uma dimensão dos direitos fundamentais ${ }^{30}$. Isso porque os direitos sociais são, antes de tudo, outra forma de tutela do indivíduo e sua dignidade ${ }^{31}$. Destarte, são igualmente garantidos por uma aplicabilidade e eficácia imediatas, isto é, pelo mero fato de constarem no texto constitucional, produzem seus efeitos essenciais, porque somente assim alcançam os fins colimados.

Das seis espécies de direitos previstos no artigo $6^{\circ}$, interessa-nos os direitos sociais do trabalhador, que são disciplinados em apartado, no artigo $7^{\circ}$. Cuidado notável que tomou o constituinte originário foi de equiparar trabalhadores urbanos e rurais, de forma que, hoje, gozam das mesmas proteções, ressalvadas as peculiaridades da realidade do homem do campo.

Deve-se destacar que o rol de direitos enunciados pelo artigo $7^{\circ}$ não é exaustivo, pois foram invocados ainda outros direitos que visem "a melhoria de sua condição social”. Partindo de tal premissa, cumpre ressaltar algumas garantias de maior vulto, resumidas na tríade trabalho, descanso, salário.

Da interpretação literal do texto político, vê-se que a Constituição Federal não estipulou um direito específico ao trabalho. Todavia, seu reconhecimento é imperativo, a partir das previsões esparsas encontradas, como no artigo $1^{\circ}$, IV, que cita o trabalho como fundamento da República e o artigo 193, que declarada o primado do trabalho.

\footnotetext{
${ }^{30}$ É essa a posição que vem ganhando forma no âmbito do STF, conforme se infere da decisão proferida nos autos da ADI 1946 / DF, onde a licença maternidade foi aventada como direito fundamental, em acórdão da lavra do então Ministro Sidney Sanches.

${ }^{31}$ Na lição de Amauri Mascaro Nascimento, têm o escopo de contribuir para a preservação dos direitos individuais. O doutrinador exemplifica uma série de conexões entre os direitos fundamentais e tutelas especificadas ao trabalhador pelo artigo $7^{\circ}$ da CRFB: (i) o direito de organização sindical é expressão da liberdade; (ii) o direito de negociação coletiva é repercussão da autonomia privada; (iii) pó direito de greve se funda na autotutela. (NASCIMENTO, Amauri Mascaro. Op. cit. p. 492)
} 
O direito social ao trabalho comporta várias leituras, que, muito antes de se enfrentarem, na verdade, são complementares. Assim, deve ser entendido como o direito ao acesso a uma formação profissional, e ainda como uma proteção contra despedidas arbitrárias - ao menos por meio de compensação em pecúnia ${ }^{32}$ - nos termos do artigo $7^{\circ}$, I, CRFB.

A garantia ao tempo de serviço, preceituada no inciso III do artigo $7^{\circ}$, por muito tempo foi apontada pela doutrina como uma opção da Constituição para abrandar a imposição do inciso I. Conforme explica o professor Aluysio Sampaio $^{33}$, esse direito do trabalhador era interpretado, erroneamente, pela doutrina, como uma via aberta para a demissão sem justa causa, compensada pelo recebimento de um determinado valor.

Nada mais absurdo. A garantia inserida no ordenamento constitucional pelo precitado inciso inaugura um verdadeiro patrimônio reservado ao trabalhador, para ser usado em casos extraordinários, previstos em lei, como a aquisição de casa própria, custeio de tratamento de moléstia grave, etc. Contraria as inspirações protetivas do texto político imagina que alguma disposição constitucional estimule o desemprego. No mais, as compensações pelo desamparado repentino provocado por uma possível demissão são trazidas pelo seguro-desemprego e o aviso prévio.

O seguro desemprego, de que trata o inciso II do artigo citado, é benefício concedido a todo empregado dispensado sem justa causa, trabalhador com contrato suspenso em virtude de participação em curso de qualificação profissional, oferecido pelo empregador, conforme convenção ou acordo coletivo celebrado para esse fim, entre outros. Esse benefício permite a assistência financeira temporária àquele que, sem culpa, viu-se desprovido das verbas de natureza alimentar com as quais vinha regularmente contando. Por

\footnotetext{
32 "Proteger a relação de emprego é, em princípio, impedir que se extinga, que possa ser desfeita sem atender aos direitos do trabalhador". (NACIMENTO, Amauri Mascaro. Direito do trabalho na constituição de 1988. São Paulo: Saraiva, 1989. p. 47).
} 
seu turno, o aviso prévio (artigo $7^{\circ}$, inciso XXI) assegura que, através do antecipado conhecimento da eminência do desemprego, o trabalhador depreenda esforços na busca por uma nova contratação.

Afim de assegurar ao trabalhador condições dignas de trabalho, o constituinte de 1988 reconheceu ainda que sua saúde física e psíquica depende de certos períodos de inatividade profissional, que pudessem ser convertidos em dedicação a outras esferas de sua vida. Em outras palavras, alguns incisos do artigo $7^{\circ}$, ao exigirem interrupções na labuta do trabalhador, reconhecem-no não apenas como mão de obra produtiva, mas também como ser social. Daí resultam limitações de tempo de trabalho no curso do dia, da semana e do ano, além de outras excepcionais. Nessa esteira podemos situar os incisos XII e XIV, que impõem jornadas de oito e seis horas diárias, respectivamente; inciso $\mathrm{XV}$, garantidor do repouso semanal remunerado; inciso XVII, que trata das férias anuais; incisos XVIII e XIX, sobre licença maternidade e paternidade.

Sem qualquer sombra de dúvida, os direitos referentes ao trabalhador de maior relevo são os relativos ao salário. O sistema de salários é um fundamento essencial para a consolidação do absoluto repúdio que o ordenamento guarda com relação ao trabalho escravo. Por isso, a Constituição Federal estipulou regras para a fixação das verbas a serem recebidas a título de salário. É o que se propõe a previsão do salário mínimo (inciso IV), o qual deverá suprir necessidades vitais e básicas do trabalhador, razão pela qual não poderá faltar nem mesmo àqueles que recebem remuneração variável (inciso VII). No entanto, a fixação de uma quantia mínima à existência condigna não anula o dever do trabalhador levar em conta a complexidade do trabalho exercido, para que sejam fixados pisos mais justos para cada categoria (inciso V). De igual sorte, são direitos do trabalhador a serem observados no momento da fixação da remuneração: remuneração do trabalho noturno superior à do

\footnotetext{
${ }^{33}$ SAMPAIO, Aluysio. Fundo de garantia de tempo de serviço e estabilidade com indenização. São Paulo: Editora RT, 1971. p. 27.
} 
diurno (inciso IX); remuneração do serviço extraordinário superior, no mínimo, em cinqüenta por cento à do normal (inciso XVI); adicional de remuneração para as atividades penosas, insalubres ou perigosas, na forma da lei (inciso XIII).

Superado o momento da fixação do salário, dois outros mecanismos buscam sua defesa no curso do contrato. O primeiro, contido no inciso VI do artigo $7^{\circ}$, veda a redução dos salários do trabalhador, salvo cláusula de acordo ou convenção coletiva. E o segundo, trazido pelo inciso X, que criminaliza a retenção do salário pelo empregador. Tendo em vista que se trata de direito adquirido pelo trabalho no momento em que presta o serviço a que fora contratado, o empregador é mero detentor daquela verba, e, se não a entrega ao legítimo proprietário, incorre no crime de apropriação indébita.

\subsection{Previsões internacionais de proteção ao trabalhador}

A constatação da significativa relevância no desenvolvimento econômico e social de uma comunidade fomentou, em diferentes momentos, as legislações de diversos Estados, seja individualmente ou organizados em cúpulas, a necessidade de resguardá-lo em disciplina específica.

Em 1995, durante a Cúpula Mundial sobre Desenvolvimento Social, realizada em Copenhague, um programa de ação previa a proibição do trabalho forçado e do trabalho infantil, a liberdade de associação e negociação coletiva, igualdade de remuneração por um trabalho de igual valor e não discriminação no trabalho como direitos básicos de todo e qualquer trabalhador, a serem protegidos universalmente, sem reservas.

Três anos depois, a Declaração da Organização Internacional do Trabalho, na Conferência Internacional do Trabalho de 1998, esboçou freios de ordem social à globalização da economia. Em que pese toda a importância desta para o crescimento econômico, foram delimitados princípios irrevogáveis 
relativos aos direitos fundamentais, que seguem a mesma tendência da reunião em Copenhague: a liberdade sindical e o reconhecimento efetivo do direito de negociação coletiva; a eliminação de todas as formas de trabalho forçado ou obrigatório; a abolição efetiva do trabalho infantil; a eliminação da discriminação em matéria de emprego e ocupação. 


\section{O pacto laboral como fonte de poderes e deveres}

\subsection{0 contrato de trabalho}

Poucos doutrinadores aventam um conceito cerrado de contrato de trabalho, sendo uma opção recorrente apenas a exposição dos seus elementos caracterizadores, que a Consolidação das Leis do Trabalho preceitua em seus artigos $2^{\circ}$ e $3^{\circ}$ dentro das definições de empregador e empregado, que mais adiante serão esmiuçadas.

Em que pese tal resistência, o professor Arnaldo Süssekind assim conceitua o instituto em análise:

(...) negócio jurídico em virtude do qual um trabalhador obriga-se a prestar pessoalmente serviços não eventuais a uma pessoa física ou jurídica, subordinado ao seu poder de comando, dele recebendo os salários ajustados ${ }^{34}$.

Compulsando a obra de Alexandre Agra Belmonte ${ }^{35}$, nota-se que o autor reconhece o contrato de trabalho como um pacto entre empregado e empregador, cujas características dão origem a deveres recíprocos.

Manuel Carlos Palomeque Lopez, por sua vez, vê no contrato de trabalho uma resposta jurídica que visa pacificar os constantes e históricos conflitos oriundos da relação de produção, que polariza, de um lado, os detentores da força de trabalho, e do outro, os detentores dos meios de produção:

\footnotetext{
${ }^{34}$ SÜSSEKIND, Arnaldo. Curso de Direito do Trabalho. 2. ed. rev. e atualiz. Rio de Janeiro: Renovar, 2004. p. 215.

35 BELMONTE, Alexandre Agra. Curso de Responsabilidade Trabalhista: danos morais e patrimoniais na relação de trabalho. 1. ed. São Paulo: LTr, 2008. p. 51.
} 
(...) mediante a prestação de trabalho assalariado ou por conta de outrem, os trabalhadores trazem ao sistema produtivo a força de trabalho necessária à realização dos bens com destino ao mercado. Em contrapartida o empresário ou titular dos meios de produção retribui, por conseguinte, através da prestação salarial, a incorporação da mão-de-obra necessária ao funcionamento da empresa. E este intercâmbio de prestações dispõe, ainda, da adequada cobertura jurídica do contrato de trabalho, cuja causa ou razão de ser objectiva é servir de suporte e facilitar as relações de produção ${ }^{36}$.

Tanto num quanto noutro conceito, é de se sublinhar a ênfase dada às obrigações decorrentes do contrato. Isto é, o conteúdo essencial do conceito de contrato de trabalho é a atribuição de conduta às partes e sua conseqüente exigibilidade.

Nada mais coerente que tal técnica de conceituação. Afinal, não se pode recorrer a requisitos formais para identificar o contrato de trabalho, já que a CLT os admite tanto de modo escrito como verbal. Basta que as partes adotem as práticas expressamente previstas em lei, independentemente do rótulo que seja dado ao ato. Por essa razão, Süssekind consagra a teoria do contrato realidade $^{37}$, para que se reconheça haver contrato de trabalho em toda relação fática em que estejam presentes a obrigação de fazer personalíssima e intransferível imposta ao trabalhador e a obrigação de pagar que cabe ao contratante, ambas nascidas do consenso das partes para criar tais deveres recíprocos inerentes à relação de trabalho e acrescidas de outros deveres acessórios.

O contrato de trabalho é gênero que comporta, dentre suas mais célebres espécies, o contrato de emprego. A doutrina segue mansa quanto às características deste último, ressalvadas poucas e inexpressivas variações nas denominações utilizadas. Vale gizá-las: de direito privado, já que é marcado pela autonomia da vontade, ainda que esta não seja absoluta; oneroso, porque a contraprestação pecuniária será sempre essencial; consensual, pois o singelo acordo de vontades tem força suficiente para fazer nascer este contrato, sem

\footnotetext{
${ }^{36}$ LOPES. Manuel Carlos Palomeque. Direito do trabalho e ideologia. Tradução de António Moreira. Coimbra: Almedina, 2001. pp. 17-18.
} 
outros formalismos, por regra; trato sucessivo, pois impõe uma relação de débito contínuo; intuito personae em relação ao trabalhador, porque os deveres estipulados não podem ser executados por outro que não aquele que foi designado pelo contratante; sinalagmático, tendo em vista que os contratantes negociam prestações equilibradas; subordinativo, já que o contrato cria um estado de dependência hierárquica entre empregador e empregado, através da imposição de deveres deste para com aquele.

\subsection{Deveres do empregado}

$\mathrm{O}$ artigo $3^{\circ}$ da CLT reconhece o empregado como tal por prestar serviços de natureza não eventual ao empregador, sob a dependência deste e mediante salário. Como se vê, mais uma vez, o sujeito é definido pelo conteúdo da obrigação assumida no momento da contratação.

Destarte, quando o empregado firma contrato de trabalho, ato contínuo, assume a posição de devedor, isto é, fica incumbido de obrigações que podem ser exigidas pela outra parte contratante. E a principal obrigação contratualmente assumida pelo empregado consubstancia um fazer, qual seja, executar o servido descriminado no pacto laboral de forma pessoal e de acordo com a estrutura organizacional de seu empregador, primando sempre pela diligência.

Para tanto, há de se subordinar juridicamente às ordens daquele que controla a atividade econômica desempenhada e assume seus riscos. Afinal, o empregado não produz para seu próprio proveito - em que pese a contraprestação que persegue - mas participa da atividade do seu empregador, por conta e em proveito dele, razão pela qual deve estar ao alcance deste o controle da prestação do serviço. Nos dizeres sempre oportunos da professora Alice Monteiro de Barros, é necessário que a participação do empregado na

\footnotetext{
${ }^{37}$ SÜSSEKIND, Arnaldo. Op. cit., p. 216.
} 
produção “implique conseqüente observância às diretivas do empregador

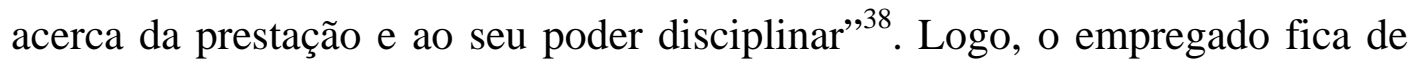
todo adstrito aos desígnios do seu empregador, situação esta que cria um estreito vínculo de dependência, conforme terminologia utilizada pela legislação consolidada, do primeiro para com o segundo. A subordinação do empregado, de tão relevante, será analisada, em título próprio, infra, em momento mais oportuno.

No mais, é de se recordar que o já consagrado princípio da boa-fé objetiva, que permeia todas as relações jurídicas experimentadas hoje, assegura ainda obrigações acessórias que viabilizam o fiel cumprimento do dever contratual principal, até mesmo, se preciso for, substituindo a vontade das partes.

Neste sentido, é dever do empregado, ainda, colaborar com seu empregador, mantendo-o a par de todos os fatos inerentes à atividade, suprimindo as necessidades inadiáveis verificadas e zelando pela ordem, moral e contratual, no ambiente de trabalho.

O empregado deve ainda fidelidade ao contratante, como decorrência da fidúcia que lhe é depositada pelo mesmo, sendo obrigado, portanto, a se abster de, intencionalmente e por interesses diversos, prejudicar o empregador, sua atividade ou posição no mercado.

São assinalados ainda pela doutrina como deveres acessórios do empregado o manejo adequado e cauteloso dos instrumentos de trabalho, para que, assim, sejam evitados danos oriundos da negligência do trabalhador. E também a prestação de serviço em consonância com a qualificação justificadamente esperada e aptidão pessoal que motivou sua contratação, de modo que, na vigência do vínculo, o empregador não deve ser surpreendido com uma produtividade aquém da idealizada ${ }^{39}$.

\footnotetext{
${ }^{38}$ BARROS, Alice Monteiro de. Curso de direito do trabalho. 2. ed. São Paulo: LTr, 2006. p. 263.

${ }^{39}$ BELMONTE, Alexandre Agra. Op. cit, pp. 51-52.
} 


\subsection{A subordinação do empregado dentro do contrato de trabalho}

Como se vê dos dois últimos atributos apontados no contrato de emprego - relação sinalagmática e subordinativa - em que pese a presença de obrigações teoricamente equivalentes, ao empregado é imposto um ônus considerável, um estado de sujeição que merece melhor atenção.

É certo que no decorrer da história, o trabalho humano passou por sensíveis transformações, e a principal delas foi o fim da visão coisificada do trabalhador - fundamento ideológico que fomentou o trabalho forçado - para que este fosse galgado ao status de pessoa propriamente dita. Deixou, portanto, de ser propriedade e se tornou o proprietário da sua força produtiva. Ocorre que, nem mesmo por isso, deve-se vislumbrar uma total e irrestrita liberdade do trabalhador. Suas pretensões e autonomia continuam submetidas ao interesse alheio, conforme anotou o professor espanhol Alfredo Montoya Melgar: "la libertad jurídica del trabajador se veía oscurecida en la práctica por la necesidad que el obrero tenía de aceptar las condiciones contractuales que le fijaba el empresario, sin otra alternativa que la del paro y la miseria”40.

Portanto, a diferença é que, modernamente, esse status de inferioridade e privação encontra guarida na forma jurídica do contrato, de modo que a legitimação da sujeição do trabalhador estaria na sua liberdade de anuir com o pacto laboral ${ }^{41}$, cessando nos momentos seguintes. No mesmo sentido entende Carlos Alberto Barata Silva ${ }^{42}$, para quem o estado de subordinação do empregado surge voluntariamente, nos momentos iniciais do contrato de trabalho, logo após as tratativas, pela concordância do empregado com o poder

\footnotetext{
${ }^{40}$ MELGAR, Alfredo Montoya. Derecho del trabajo. 2. ed. Madrid: Tecnos, 2001. p. 65.

${ }^{41}$ Orlando Gomes e Elson Gottschalk sublinham que "são aceitas, desde o início, as previsíveis conseqüências: a mais importante e onerosa é a situação de subordinação”. (GOMES, Orlando; GOTTSCHALK, Elson. Curso de direito do trabalho, 14. ed. Rio de Janeiro: Forense, 1995. p. 131).

${ }^{42}$ SILVA, Carlos Alberto Barata. Compêndio de direito do trabalho. 4. ed. São Paulo: LTr, 1986. p. 183.
} 
de comando que o empregador detém na empresa. Segundo o autor, a subordinação traduz "um status a que voluntariamente se submete o empregado”.

Vale lembrar que a sujeição da qual se trata nem sempre se concretiza nos mundo dos fatos como dependência econômica, embora este critério tenha sido reivindicado por muito tempo. Sem que se pretenda menosprezar a relevância alimentar do salário perseguido pelo trabalhador na relação empregatícia, não se pode olvidar que este diferencial fica vazio de sentindo se, numa análise casuística, alcançarmos hipóteses em que o papel de empregado é desempenhado por pessoa que não depende economicamente do seu empregador, quiçá lhe financia, como no caso de altos executivos e médicos que mantêm vários empregos.

De igual sorte, o critério invocado não pode ser técnico, no sentido do empregador deter, com exclusividade, os conhecimentos técnicos para desempenho da atividade, de modo o empregado não consiga desenvolver seus afazeres sem que o primeiro lhe forneça instruções. Nada mais inadequado à realidade atual, onde torna-se cada vez mais recorrente que o empregado mesmo é quem aperfeiçoe-se e acompanhe a evolução tecnológica do seu ofício. Então, seguindo a ótica proposta, seria forçoso concluir pela preponderância do empregado sobre o empregador ${ }^{43}$, que depende do know how daquele para dar seguimento ao empreendimento.

Destarte, falamos, a bem da verdade, numa dependência jurídica, que significa a existência de um direito - in casu, do empregador, de comandar seu empreendimento - garantido pela imposição de um dever a outrem, que pode ser entendido como o dever do empregado manter-se pautado pelos comandos do seu empregador.

\footnotetext{
${ }^{43}$ PINTO, José Augusto Rodrigues. Curso de direito individual do trabalho. 2. ed. São Paulo: LTr, 1995. p. 113.
} 
Essa relação é "conseqüência imediata da celebração do ajuste entre empregado e empregador, o qual coloca sob a responsabilidade deste último a organização e disciplina do trabalho realizado na empresa"44. Contudo, indo além, podemos dizer que esse ajuste só chega a ser firmado porque existe um interesse social do empreendimento em todos os seus níveis e que impregna toda sua estrutura, exigindo uma perfeita organização profissional do trabalho fornecido pelos seus colaboradores a fim de se atingir um bem comum de ordem econômico-social. Trata-se, pois, de um fato da instituição que dá azo à legitimação de um poder do empregador e a conseqüente sujeição do empregado.

Ademais, Délio Maranhão ${ }^{45}$, buscando livrar o trabalhador de uma condição absolutamente vulnerável aos mandos e desmandos do empregador, encontrou no próprio contrato de trabalho os limites da extensão da sua sujeição. Afinal, como visto antes e restou inconteste, a subordinação do trabalhador se legitima no citado pacto. Seguindo o mesmo espírito, diversos doutrinadores assinalam outros óbices ao estado de dependência em análise, como, à guisa de ilustração, o exercício regular das funções avençadas, a legalidade da conduta reivindicada, a razoabilidade técnica do comando, entre outros.

Mais relevante ainda é notar que a subordinação com a qual anui o empregado dentro do contrato de trabalho é objetiva, isto é, diz respeito apenas aos serviços contratados e sua execução, nada além. É a partir daí que, por exercício de lógica e razoabilidade jurídica, podemos auferir o momento em que deve cessar a ingerência do empregador sobre o empregado, que nunca deve alcançar a pessoa do prestador do serviço. Tanto é que, uma vez afrontado qualquer destes limites, nasceria para o empregado um direito de

\footnotetext{
${ }^{44}$ BARROS, Alice Monteiro de. Op. cit., p. 555.

${ }^{45}$ MARANHÃO, Délio; TEIXEIRA, João de Lima; VIANNA SEGRADAS; SÜSSEKIND, Arnaldo. Instituições de direito do trabalho. 22. ed. São Paulo: LTr, 2002. v. 1, p. 243.
} 
resistência que lhe retira da inércia servil e ressalta a sua condição de agente na relação produtiva, ainda que subordinado.

\subsection{Poderes e deveres do empregador}

O empregador tem como obrigação primordial, pagar o salário de seu contratado, remunerando a prestação do trabalho. Trata-se, portanto, de uma obrigação de dar, equivalente à obrigação de fazer que cabe ao empregado. Deve ainda primar pela aplicação das leis, dos acordos e convenções coletivas, disposições internas da empresa e, no mais, aquilo que for asseverado no contrato de trabalho.

Ao lado destas, há outras obrigações acessórias, exigidas por lei, que se manifestam, por exemplo, na anotação da CTPS, depósitos do FGTS, inscrição no PIS, preservação da imagem e da honra do trabalhador e, sobretudo, vinculadas à saúde e higiene do ambiente de trabalho.

O conceito de empregador introduzido pelo caput do artigo $2^{\circ}$ da Consolidação das Leis do Trabalho preceitua não só tal dever, mas também consolida nas mãos do empregador o poder de comando ${ }^{46}$. Este se justifica, na lição do professor Arnaldo Süssekind, “porque no regime capitalista (o empresário) assume o risco do seu empreendimento econômico"47. Por conta disso, é facultado ao empregador controlar, regulamentar e até mesmo disciplinar os componentes internos da sua estrutura produtiva, como formas de se assegurar a subordinação do trabalhador. São, por conseguinte, meios necessários, quiçá indispensáveis, ao correto funcionamento da empresa.

\footnotetext{
${ }^{46}$ Maurício Godinho condena o uso da expressão "poder hierárquico” para designar tais faculdades do empregador, para que não se amplie o alcance da relação de poder travada no contrato de trabalho. Segundo o autor, falar em hierarquia poderia dar ensejo a uma prevalência do empregador em todos os âmbitos da vida do empregado, sublinhando uma pretensa superioridade irrestrita. Por isso, é mais adequado falar em "poder de comando", "poder diretivo" ou meramente em "poder empregatício". (DELGADO, Maurício Godinho. Curso de direito do trabalho. 3. ed. São Paulo: LTr, 2004. p. 681.)

${ }^{47}$ SÜSSEKIND, Arnaldo. Op. cit., p. 261.
} 
O poder controlador, ou diretivo, permite que o empregador coordene a execução da atividade obreira em conformidade com as diretrizes e regras do seu empreendimento, já que o sucesso ou insucesso dele só lhe diz respeito. Assim, o empregador indica o modus operandi, isto é, a orientação técnica do serviço, podendo interrompê-lo e suscitá-lo à vontade ${ }^{48}$, ficando o empregado adstrito a tais comandos. É até mesmo salutar que se coordene a atividade do empregado com os fatores produtivos para a otimização dos objetivos do empreendimento.

O poder regulamentar faz do empregador legislador da sua atividade. Isto é, pode estatuir as normas regedoras do empreendimento, de caráter técnico ou organizacional. Uma organização sólida que mantenha estável toda a complexidade produtiva, em grande medida, depende da submissão de seus partícipes a regulamentos criados pelo empreendedor, antenados às condições especiais de trabalho.

Por fim, o poder disciplinar, em conformidade com a necessidade de manter a ordem no local de trabalho, permite a repressão e sanção do descumprimento das obrigações contratuais por parte do empregado. É por isso que a doutrina chega a dizer que este poder é essencial à existência e efetividade dos demais, na medida que evita os desvios na conduta esperada do trabalhador.

Tamanha supremacia do empregador abre vias para arbitrariedades e discricionariedade. Ora, como lembra Max Werber “o homem não luta pelo poder apenas para enriquecer economicamente. O poder pode ser desejado por 'si mesmo’”,49, isto é, tão apenas para servir de meio de opressão, na medida em que traz a possibilidade de se realizar sua vontade própria em uma ação, mesmo sendo essa ação contrária a vontade de outros. Daí a necessidade

\footnotetext{
${ }^{48}$ MORAES FILHO, Evaristo de; MORAES, Antonio Carlos Flores de. Introdução ao direito do trabalho. 7. ed. São Paulo: LTr, 1995. p. 255.

${ }^{49}$ WEBER, Max. Ensaios de sociologia. Organizado por H. H. Gerth e C. Wrigth Mills. Tradução de Waltersin Dutra. 5. ed. Rio de Janeiro: LTC, 2002. p. 126.
} 
imperiosa de limitações, afim de que sejam evitadas mitigações aos direitos e liberdades do trabalhador.

Em outras palavras, é inquestionável que é dado ao empregador dirigir a atividade de seus subordinados, mas nos estritos limites do que é indispensável à prestação do serviço, sem se olvidar, primeiro, das disposições contratuais, segundo, dos direitos inerentes à sua condição de pessoa e que lhe são assegurados pelo ordenamento jurídico como um todo, que já foram abordados em capítulo específico, supra. O poder em estudo recai, sempre, sobre a atividade, jamais sobre a pessoa. Nesse sentido, é elucidativa a lição da professora curitibana Maria Aparecida Alkimin ${ }^{50}$, para quem os direitos garantidos ao trabalhador pela Constituição da República de 1988 são limitações naturais e legais do poder de direção e ao exercício do jus variandi do contratante.

Portanto, se a doutrina é uníssona em reconhecer o dever de pagar salários como a obrigação principal do empregador na relação de trabalho, não pode ser menor o enfoque sobre o dever de respeitar e salvaguardar a dignidade do trabalhador, em vistas da sua condição de pessoa humana, tutelada pela Constituição da República ${ }^{51}$.

Se na legislação brasileira a identificação desses limites intrínsecos ao contrato de trabalho depende de uma leitura interligada de dispositivos esparsos no ordenamento, alguns países já deram especial atenção ao dever do

\footnotetext{
${ }^{50}$ ALKIMIN, Maria Aparecida. Violência na relação de trabalho e proteção à personalidade do trabalhador. 1. ed. Curitiba: Juruá, 2009. pp. 76-77.

${ }^{51} \mathrm{O}$ professor Délio Maranhão já lecionava neste sentido, ao expor que "acima de tudo, tem o empregador a obrigação de respeitar a personalidade moral do empregado na sua dignidade absoluta de pessoa humana”. (MARANHÃO, Délio et al. Op. cit. p. 261). No mesmo sentido está a doutrina de Jorge Pinheiro Castelo, para quem "o mais importante direito e a precípua obrigação contratual do empregador inerente ao contrato de trabalho não tem natureza patrimonial. E é justamente o dever de respeito à dignidade moral da pessoa do trabalhador, aos direitos relativos à personalidade do empregado, cuja violação significa diretamente violação de direito e obrigação trabalhista e do contrato de trabalho". (CASTELO, Jorge Pinheiro. Tutela antecipada no processo do trabalho. São Paulo: LTr, 1999. v. 2, p. 215). É ainda a lição de Eduardo Baracat, para quem "as partes devem, mutuamente, trabalhar para se atingir um desenvolvimento socioeconômico, tendo-se no vértice axiológico a dignidade da pessoa humana, e, apenas após, o direito à propriedade”. (BARACAT, Eduardo Milléo. A boa-fé no direito individual do trabalho. São Paulo: LTr, 2003. p. 244).
} 
empregador de tutelar a dignidade do empregado. É o caso da Itália, no artigo 2.087 de seu vigente Código Civil ${ }^{52}$. É um verdadeiro exemplo a ser seguido.

\subsection{Conseqüências do descumprimento dos deveres contratuais}

O saudoso professor Miguel Reale ${ }^{53}$, ao investigar a essência do dever jurídico, identifica nas relações desta natureza a presença de duas ou mais pessoas atadas entre si por conta de uma força transubjetiva que lhes atribui certo comportamento e certas exigibilidades. Significa dizer, em outras palavras, que as pretensões deduzidas em uma relação que se entende jurídica gozam de garantias do seu fiel cumprimento ou, no pior dos mundos, que assegurem ao lesado uma vantagem equivalente à que faria jus no curso regular das coisas.

Seguindo as lições de Sérgio Cavalieri Filho ${ }^{54}$, a responsabilidade civil surge quando praticado um ato ilícito, ou seja, um comportamento voluntário que infringe um dever jurídico, oriundo do contrato ou das normas gerais de direito. Uma vez transgredida a conduta imposta numa dessas duas fontes, nasce o dever jurídico sucessivo de reparar o prejuízo decorrente da violação de uma outra obrigação.

Não é outra senão esta a realidade da relação trabalhista, e a isso dá-se o nome de responsabilidade trabalhista, isto é, o dever de reparar o dano moral ou patrimonial causado por uma das partes do contrato de trabalho ${ }^{55}$. Uma vez vendo frustrada a expectativa legítima que mantinha acerca do avençado, empregador e empregado têm ao seu alcance mecanismos de recomposição das

\footnotetext{
${ }^{52}$ Art. 2087. L'imprenditore e tenuto ad adottare nell'esercizio dell'impresa le misure che, secondo la particolarità del lavoro, l'esperienza e la tecnica, sono necessarie a tutelare l'integrità fisica e la personalità morale dei prestatori di lavoro.

${ }^{53}$ REALE, Miguel. Filosofia do Direito. 19. ed. São Paulo: Saraiva, 2002. p. 403.

${ }^{54}$ CAVALIERI FILHO, Sergio. Programa de responsabilidade civil. 7. ed. São Paulo: Atlas, 2007. p. 2.

${ }^{55}$ BELMONTE, Alexandre Agra. Op. cit., p. 50.
} 
perdas daí decorrentes, em nome da segurança jurídica que deve cercar todas as relações sociais que envolvam direitos, como é o trabalho.

Estas perdas têm, habitualmente, caráter patrimonial, dada a onerosidade própria da relação empregatícia, e por isso mesmo, os desdobramentos do descumprimento contratual gravitam - mediata ou imediatamente - em torno da supressão ou agregação de verbas indenizatórias quando da resolução do vínculo.

Neste sentido, se por culpa do empregado, advém quebra das expectativas contratuais, é dado ao empregador, valendo-se do seu poder disciplinar, impor sanções. Estas, seja por via pedagógica, como nas advertências, ou por alterar a economia do trabalhador, nas hipóteses de suspensão com conseqüente perda de salários no período correspondente, pretendem restabelecer a normalidade da relação empregatícia. Por outro lado, quando a retomada do vínculo se revelar inviável, o contrato de emprego poder vir a ser resolvido, e o empregado inadimplente perderá direito às verbas rescisórias, exceto as pertinentes a direitos adquiridos, como férias e salário.

Por outro lado, também se deve cogitar do empregador que, adotando conduta incondizente com o pacto laboral, torna insustentável a continuação da prestação de serviços, por estar desvirtuada. Quando isto ocorre, abre-se ao trabalhador a possibilidade de ver reconhecida a rescisão do contrato, nos termos e condições do artigo 483 da CLT, valendo-se, para tanto, da via judicial. A Consolidação, aliás, enumerou no artigo precitado, taxativamente, sete condutas que dão azo ao reconhecimento da dita rescisão indireta.

Pela alínea "a” do artigo 483 da CLT, o empregador, por culpa, compromete a lisura do contrato firmado com seu empregado, quando exige deste serviços superiores às forças sejam físicas ou intelectuais do mesmo. De igual sorte, é falta grave hábil para fazer ser reconhecida a rescisão indireta a exigência da realização de atividades fora das previstas em contrato e destoantes da função designada. 
Noutro giro, embora o empregador tenha o poder de mando já desdobrado nas laudas anteriores, a alínea "b” da norma em questão veda que ele se exceda no rigor com que exerce sua autoridade, sob pena de se tornar culpado pelo rompimento do vínculo. Esses excessos incluem, a título de ilustração, a falta de educação, desrespeito, discriminação e punições desproporcionais ante o tipo de falta cometida.

Toda vez que o empregador ordena que o empregado execute uma atividade ou serviços potencialmente danosos à integridade física do subordinado, sem que este risco advenha naturalmente do tipo de serviço prestado, está, por culpa, segundo a alínea “c”, maculando o contrato de trabalho.

A alínea “d” do artigo 483, por sua vez, traz a hipótese mais cristalina de quebra contratual. É quando o empregador deixa de cumprir com seus deveres contratuais como, por exemplo, pagamento dos salários no prazo, décimo terceiro salário e férias vencidas.

Ainda seguindo o caminho desenhado pela CLT, pela alínea "e" do artigo precitado, o empregador que praticar atos lesivos à honra e boa fama do empregado ou de qualquer pessoa de sua família, tais como calúnia, injúria, difamação e afins está descumprindo o contrato de trabalho e deverá ser responsabilizar por isso.

A ofensa física é passível de responsabilidade criminal em qualquer tipo de relação social, e desta regra não foge o vínculo trabalhista. Empregador e empregado jamais poderão chegar às vias de fato motivados por questões do contrato de trabalho. No entanto, deve-se ressalvar a hipótese da legítima defesa praticada pelo empregado. Se o empregado sofre uma agressão física e, para se defender, retribui à ofensa ao empregador, não se retira do mesmo a proteção da rescisão indireta. A falta grave foi cometida pelo empregador, e a forma de defesa, se proporcional, desprendida pelo empregado não tem o condão de deturpar essa realidade. 
O artigo $7^{\circ}$, inciso VI da Carta Política consagra o princípio da irredutibilidade de salários, excetuando a regra apenas nos casos de acordo ou convenção coletiva de trabalho. Destarte, a alínea "g" do artigo 483 da CLT nada mais é que reflexo da norma constitucional, porque, se o empregado trabalha por peça, tarefa ou comissão e o empregador as reduz unilateralmente, seja na quantidade ou no percentual, isso importa em redução dos ganhos do trabalhador, o que prejudica a expectativa econômica que mantinha para com o pacto laboral.

Em todos esses casos, o empregador torna intolerável a relação trabalhista, e o contrato se extingue por sua culpa. Então, o empregado que se vê desprovido das verbas de natureza alimentar sobre as quais mantinha expectativa legítima, terá direito às verbas resilitórias que lhe conferirão uma assistência financeira ainda que temporária. Significa dizer que haverá extinção do vínculo por culpa do empregador, razão pela qual a lei faz dele devedor de todas as verbas previstas no ordenamento para o quadro de demissão sem justa causa.

Quando, por fim, empregado e empregador dão causa, simultaneamente, à degeneração do vínculo de trabalho, não há uma única expectativa financeira a ser recuperada. Então, a solução é que a indenização seja divida pela metade, diante da culpa eficiente para causar o dano das partes contratantes.

Ocorre que, como se pode ponderar das hipóteses trazidas à baila, nem sempre as conseqüências do descumprimento do contrato de trabalho se encerram em termos financeiros, com a reparação do patrimônio do lesado. Isto porque a mera recomposição pecuniária das perdas, por vezes, não é suficiente para reparar o dano provocado. Em diversas ocasiões, valores extrapatrimoniais da parte contratante é alcançado pela conduta do outro, como, por exemplo, nos casos de ofensa à imagem, agressão psicológica e afins. Por essa razão, a responsabilidade trabalhista pretende compor também os danos morais impostos à pessoa humana. 
Não raro, os danos de natureza imaterial podem ser verificados até mesmo antes da celebração do contrato, como, por exemplo, nas hipóteses de discriminação durante o processo seletivo para vaga de emprego. Ou ainda após a extinção do vínculo, quando é negado ao trabalhador a verdade sobre suas qualidades profissionais numa carta de referência. Ora, sendo o dano oriundo de uma relação de emprego - seja ela pretensa, presente ou finda - fica patente a responsabilidade trabalhista e o dever de reparar ${ }^{56}$.

Desta feita, vê-se que nosso ordenamento impõe ao empregador a obrigação de tratar dignamente seus subordinados, respeitando liberdades de pensamento, trabalho, intimidade, honra, boa fama, além de se abster de atos que traduzam ofensa de qualquer natureza, sob pena de ter de reparar o dano que causou direta ou indiretamente.

\footnotetext{
${ }^{56}$ Oportunamente, deve-se registrar o pronunciamento do egrégio Supremo Tribunal Federal, que em acórdão sob a relatoria do Ministro Sepúlveda Pertence, concluiu não ser relevante para fixação da competência da Justiça do Trabalho que a solução da lide remeta a normas civilistas. É suficiente que o fundamento do pedido se assente na relação de emprego, inserindo-se no contrato de trabalho. Cf. Conflito de Jurisdição nº 6959-6, Distrito Federal.
} 
3

\section{A violência moral provocada pelos excessos do poder diretivo}

\subsection{Contextos contemporâneos}

É seguro afirmar que o domínio do trabalhador sobre suas próprias forças produtivas traduz uma das principais conquistas da humanidade. Deixar de ser mero instrumento de produção para se tornar agente principal desta constituiu etapa de grande relevo na luta pelas liberdades individuais e pelo bem-estar social.

No entanto, a face social da transformação veio seguida de um virulento processo de modernização do mercado de trabalho, sobretudo a partir no final do século XX. Esta foi fomentada pelo nascimento de um mercado globalizado, composto por novos atores, agora descompromissados com as pretensões protetivas do Estado. Entre trabalhadores livres e iguais perante a lei, instauraram-se novas ideologias de produção, essencialmente negadoras das disparidades de forças e possibilidades existentes entre os trabalhadores e insegura quanto a manutenção do emprego. Surge não só uma economia global, mas também uma nova ética do trabalho que se caracteriza pela degradação da figura humana.

A nova organização do trabalho criou contextos de exigências, acirrou competitividade, exigiu a reestruturação de tempo e instituições mais flexíveis. Enfim, foram adotadas novas formas de poder e controle. A palavra de ordem que se impôs no mercado de trabalho foi "flexibilização", que, na prática, significa menos regras ao contrato de trabalho, que tende a ser cada vez mais precário. Ao mesmo passo, desde então, vige um clima de pressão pela 
máxima produtividade de baixo custo. O constante de medo do desemprego incute no trabalhador a tolerância ante às práticas autoritárias, evidenciando uma verdadeira "cultura do contentamento geral".

As organizações deram outra conotação à liberdade do trabalhador: passou a ser responsabilidade exclusiva de cada indivíduo sobreviver ao ritmo do empreendimento, ou, em outras palavras, suportar a ferocidade do mercado e vencê-la, para só assim destacar-se como profissional realmente qualificado. Ao empregador cabe apenas coordenar os resultados, já que está na esfera individual de cada trabalhador o meio utilizado.

Exige-se do trabalhador, em total dissonância com seu aspecto humano, a mesma elasticidade que os negócios apresentam dentro de uma economia global e competitiva. Sua permanência no mercado pós-moderno depende da velocidade com que consegue se adequar às transformações ideológicas e sistêmicas do empreendimento, como se fosse possível fragmentar e descontinuar um indivíduo, numa dinâmica de incertezas, tal qual se faz com um processo produtivo.

Muito mais que especializações e experiências, o diferencial da mão de obra passou a ser a capacidade de inovação constante, a flexibilidade para viver e administrar ambientes em mudança, a reação ante aos desafios e riscos ${ }^{57}$. Foi dada, portanto, uma nota de precariedade às relações humanas, dentro de uma lógica de mudanças contínuas e incertezas. Com isso, coloca-se em prova o caráter pessoal dos seus agentes. Relações de curto prazo são tão superficiais quanto irresponsáveis e ameaçadoras, vez que resta pouco espaço para vínculos estáveis de lealdade, respeito e solidariedade.

As conseqüências destas relações instáveis e estressantes de trabalho incitam à perda do sentido do trabalho como profissão, carreira e continuidade;

\footnotetext{
${ }^{57}$ BARRETO, Margarida. Violência, saúde e trabalho: uma jornada de humilhações. São Paulo: PUC, 2003. p. 98.
} 
ao desapego e ao descrédito daquilo que se relacione ao passado; à negação das referências que constroem e significam a história de vida de cada indivíduo ${ }^{58}$.

No meio de tantas tensões, despontam situações que sublinham com clareza aquilo que, muito antes, Sigmund Freud chamava de "instabilidade interior do homem e sua conseqüente sede de autoridade”. Sejam disputas narcisistas pelo poder ou mero desenrolar da guerra pela sobrevivência no selvagem mundo do trabalho, o resultado é a nova chaga trabalhista do século XXI, na definição que Iñaki Piñuel y Zabala ${ }^{59}$ dá ao assédio moral.

\subsection{Conceito}

As primeiras pesquisas relativas ao processo de degradação psicológica do trabalhador provocado por abusos de autoridade surgiram na década de 1980. Na universidade de Estocolmo, o Doutor Heinz Leymann foi pioneiro no estudo do assédio moral, quando identificou que há maior proporção de pessoas assediadas em atividades nas quais as relações de autoridade são mais sensíveis, como na área de educação e em instituições religiosas. Para ele, tais ramos do mercado de trabalho apresentam uma estrutura que, pelos mais variados motivos - desde a autopromoção até a mitigação da concorrência -, estimularia condutas tendentes a minar a integridade psicológica do trabalhador ${ }^{60}$.

Em 1995, psicólogos alemães estimaram que o custo anual do assédio psicológico na Alemanha estava em torno de 100 milhões de marcos. Na indústria britânica, girava em torno de 18 milhões de jornadas de trabalho perdidas. Estes números foram suficientemente alarmantes para trazer uma

\footnotetext{
${ }^{58}$ SENNETT, Richard. A corrosão do caráter: as conseqüências pessoais do trabalho no novo capitalismo. Trad. Marcos Santarrita. Rio de Janeiro: Record, 1999. p. 27.

${ }^{59}$ ZABALA, Iñaki Piñuel y. Mobbing: como sobreviver ao assédio psicológico no trabalho. Trad. Alda Machado. São Paulo: Loyola, 2003. p. 51.

${ }^{60}$ DAVENPORT, Noa; SCHWARTZ, Ruth Distler; ELLIOT, Gail Pursell. Mobbing: emotional abuse in the american workplace. Iowa: Civil Society Publishing, 2002. p. 21.
} 
onda recente de novos estudos sobre o fenômeno da violência moral contra o trabalhador.

Em que pesem tais esforços, a definição do que seja o assédio moral ainda traz muita cizânia na doutrina jurídico-trabalhista pátria, já que falta uma previsão específica sobre o tema. No entanto, uma definição clara é necessária para o projeto de técnicas de prevenção ou correção do problema no ambiente de trabalho. É por isso que toda abordagem que se pretenda fazer acerca de um conceito norteador demanda, necessariamente, uma incursão em estudos de psicologia e sociologia. Estes têm o mérito de levar em conta o contexto em que se insere a relação de assédio, reconhecendo, com isso, que não se pode deixar de investigar o conjunto de valores associados à violência.

Marie-France Hirigoyen ${ }^{61}$, em incansáveis estudos sobre o tema, investigou a terminologia utilizada. Assediar significa submeter alguém, sem trégua, a pequenos e repetitivos ataques. Já o termo moral reflete a dicotomia entre o bem e o mal, ou seja, os limites do aceitável dentro de um padrão social e objetivo. Com efeito, a psiquiatra definiu assédio moral como "qualquer conduta abusiva (gesto, palavra, comportamento, atitude) que atente, pela repetição ou sistematização, contra a dignidade ou integridade psicofísica de uma pessoa, ameaçando seu emprego ou degradando o clima de trabalho”.

Destarte, o assédio moral consiste na submissão constante e freqüente a sutis ataques de ordem psicológica que, somente tomados em conjunto, no tempo e no espaço, é que evidenciam um processo de destruição ${ }^{62}$. Na mesma linha está o conceito do Doutor Heinz Leymann, que considera o assédio moral

\footnotetext{
${ }^{61}$ HIRIGOYEN, Marie-France. Mal-estar no trabalho: redefinindo o assédio moral. Rio de Janeiro: Bertrand Brasil, 2002. p. 17.

${ }^{62}$ Márcia Novaes Guedes identifica dois elementos essenciais no assédio moral: o notório fim de desestabilizar emocionalmente a vítima e, sobretudo, a regularidade dos ataques. (GUEDES, Márcia Novaes. Terror psicológico no trabalho. 2. ed. São Paulo: LTr, 2005. p. 35). Por conta da necessidade dessa sistematização da conduta lesiva para configurar o assédio moral, Sônia Nascimento sugere um interregno de, no mínimo, um ano de insistência na prática ofensiva. Pelo excesso de objetivação, que chega a desconsiderar variações fáticas na intensidade da agressão, segue isolada. (NASCIMENTO, Sonia Mascaro. O assédio moral no ambiente de trabalho. Revista LTr. São Paulo, ${ }^{\circ}$ 8, p. 924, ano 2004).
} 
como um "processo de destruição que se compõe de uma série de procedimentos hostis que, isoladamente, poderiam parecer inofensivos, mas cuja repetição constante tem efeitos perniciosos"63.

No ramo jurídico, Vilja Marques conceituou o assédio moral como a "exposição dos trabalhadores a situações humilhantes e constrangedoras, repetitivas e prolongadas, durante a jornada de trabalho e no exercício de funções profissionais" ${ }^{64}$. Vólia Bonfim Cassar identificou "condutas abusivas praticadas pelo empregador direta ou indiretamente, sob o plano vertical ou horizontal, ao empregado",65.

Portanto, é possível identificar alguns traços marcantes do psicoterrorismo no local de trabalho. Há sempre um ato perverso, do ponto de vista psicológico, contra um trabalhador. $\mathrm{O}$ assediador procura atingir a vítima na sua qualidade pessoal de maior destaque. Verifica-se um claro objetivo de destruir a imagem pessoal ou pública da vítima, independentemente de tal resultado seja ou não alcançado ${ }^{66}$. O assediado tem sua reação atada, seja porque tem dúvidas sobre as intenções do assediador ou porque teme e respeita a autoridade deste.

O assédio não se caracteriza como um conflito, pois este pode até mesmo contribuir para o crescimento da atividade organizada. A violência moral, a seu turno, em nada acrescenta, porque traduz situações de caráter comunicativo que infligem ao indivíduo graves prejuízos de ordem psicofísica. Trata-se de um processo deliberado de destruição que, com freqüência, independe de atritos.

\footnotetext{
63 ZABALA, Iñaki Piñuel y. Op. cit. p. 53.

${ }^{64}$ ASSE, Vilja Marques. Um fenômeno chamado psicoterrorismo. Revista LTr, 68, n 7, jul. 2004, p. 819.

${ }^{65}$ CASSAR, Vólia Bonfim. Direito do Trabalho. 3. ed. Niterói: Impetus, 2009. p.744.

${ }^{66}$ Alice Monteiro Barros traz a relevante recomendação de desvincular o assédio moral de um resultado lesivo no plano psíquico do trabalhador. Afirma que, do contrário, a tipificação da conduta do assediador dependeria da vulnerabilidade da vítima eleita. Logo, é suficiente que o ofensor queira provocar o dano psíquico ou moral ao empregado, "para marginalizá-lo no seu ambiente de trabalho". (BARROS, Alice Monteiro de. Op. cit.. p. 890).
} 


\subsection{A vítima do assédio moral}

A história do Direito revela diversas perspectivas sobre a participação da vítima na solução dos conflitos de interesse. Na Antigüidade os litígios eram resolvidos pela vingança. A vítima reagia à agressão como podia, com todos os meios ao seu alcance, podendo ser indicada como essencial para dirimir a controvérsia. Em momento posterior, esse papel foi minguando e a reparação do dano passou a ser gerenciada por um terceiro, que interfere no conflito. É nessa seara que surge a necessidade do ofendido recorrer às autoridades públicas para formular seu pleito. O que se pode verificar é que há uma verdadeira expropriação do conflito, de modo que o poder centralizado toma o lugar da vítima original da ofensa.

Nesse passo, na Idade Média, já se percebe um distanciamento da vítima das decisões dos conflitos, que passa para as mãos dos senhores feudais, da Igreja e das Monarquias. No Estado Moderno à vítima é relegado um papel meramente testemunhal. É neutralizada pelo Estado, que detém o monopólio da justiça. Isso despersonaliza o ofendido, pois o ato lesivo deixou de ser visto como um conflito interpessoal, para ser entendido como um mal para a sociedade inteira.

O Direito Penal, mais especificamente no ramo da criminologia, é pioneiro na retomada da atenção para o estudo do ofendido. Essa recuperação é relevante por admitir que a compreensão de um fenômeno violento depende, em muito, das conseqüências da ação, as quais, necessariamente, consubstanciam-se na vítima.

Chama-se vítima do assédio moral no ambiente do trabalho o profissional contra o qual são dirigidas reiteradas ações e omissões humilhantes. Isso pode se dar através de uma comunicação, escrita ou verbal, pejorativa, tendente a desqualificar o trabalhador do ponto de vista pessoal ou profissional. Outro exemplo é a alienação forçada do trabalhador nas decisões 
da empresa e, até mesmo, na produção, a partir da supressão de atribuições ou isolamento geográfico. Pode-se cogitar, ainda, do uso abusivo do poder disciplinar ou da delegação de tarefas alheias ao contrato ou sabidamente irrealizáveis.

Para ser vítima, o obreiro precisa manter algum nível de interação e dependência com a atividade organizada patronal, mesmo que indiretamente. Deste modo, é possível que uma gama variada de trabalhadores ocupem a posição de assediado, desde temporários a terceirizados, valendo, porém, a ressalva da professora Maria Aparecida Alkimin:

Evidentemente, uma pessoa que não participe ativamente do ambiente de trabalho não poderá ser vítima de asseio moral, pois em razão da necessidade de reiteração e sistematização da conduta assediante, a vítima tem que integrar a organização do trabalho de forma permanente e sistemática ${ }^{67}$.

É certo que, pela dinâmica do assédio moral, qualquer trabalhador pode ser “eleito” como vítima. No entanto, há esforços, principalmente da psicologia, em identificar espécies de trabalhadores que, usualmente, são mais atacados pela perversão do ambiente laboral. É preciso atentar que, embora pesquisas não apontem um perfil específico para o assediado, existem contextos profissionais que facilitam o assédio e situações nas quais as pessoas correm maior risco.

A pesquisadora francesa Hirigoyen ${ }^{68}$ relaciona alguns destes, a começar pelas pessoas atípicas, isto é, que fogem a um estereótipo da organização. Como o estopim da violência é um diferencial, torna-se muito tênue a linha que separa o assédio moral a pessoas atípicas da discriminação. Pessoas que resistem à padronização traduzem verdadeira dificuldade de adaptação ao grupo ou à estrutura da empresa, e também podem ser, facilmente, vítimas do assediador.

\footnotetext{
${ }^{67}$ ALKIMIN, Maria Aparecida. Assédio moral na relação de trabalho. 2. ed. rev. atual. Curitiba: Juruá, 2009. p. 43.

${ }^{68}$ HIRIGOYEN, Marie-France. Op. cit. pp. 219-225.
} 
Pessoas menos produtivas - seja por uma causa transitória ou uma inabilidade específica -, costumam ser assediadas pelo grupo que, intolerante, busca ampliar suas cotas de desempenho e são mais conformados com os requisitos da empresa.

Ainda mais usual e lesivo é o assédio praticado contra assalariados especialmente protegidos. São mulheres grávidas, representantes sindicais, cotistas, enfim, uma série de profissionais que gozam de prerrogativas como estabilidade ou reserva de vagas. Estes trabalhadores representam uma afronta ao jus variandi do empregador e, por isso, é comum a tentativa de miná-los da estrutura produtiva, através do assédio moral.

A jurisprudência pátria também já revelou que trabalhadores que reclamam judicialmente seus direitos em face do empregador, mas sem desvincular-se da atividade, são constantemente vítimas de expedientes com notório fim de revide.

\subsection{0 agressor}

A lógica moderna da produção, agravada pela estrutura hierárquica das organizações, faz com que, num ambiente competitivo como o de trabalho, a perversão moral possa ser desencadeada pelo empregador, por pares, ou até mesmo por subordinados. É mais usual o primeiro cenário, ou seja, o chamado assédio vertical descendente, porque a simetria entre ofensor e vítima abre maiores possibilidades de reação e uma menor tolerância aos atos abusivos.

É preciso sublinhar que, embora seja comum a presença do vínculo de subordinação e poder entre assediador e assediado, isso não é um requisito elementar para a configuração da violência moral. Não se pode olvidar que, conforme posição uníssona da doutrina, ela pode ser praticada pelo empregado contra seu superior ou contra colaterais. 
Admitida a possibilidade de ocorrência do assédio vertical ascendente e do assédio horizontal, o foco principal do estudo doravante, é a humilhação provocada pelo empregador, como forma de desvio do poder direito assegurado a este.

É da essência do contrato de emprego o nascimento de uma relação de subordinação do trabalhador ao empregador. Reconhece-se que este, por concentrar os riscos da atividade desenvolvida, precisa ter o direito de coordenar os serviços que lhe são prestados, ditando os fatores de produção da empresa.

Trata-se, portanto, de um poder de comando absolutamente lícito, posto que é necessário à saúde do empreendimento, que não poderá ser suprimido do empregador. Na moderna lição de Vólia Cassar ${ }^{69}$, o empregado não pode se esquivar do dever de obediência na conduta profissional, sujeitando-se às regras fixadas pelo empregador, desde que legais e não abusivas.

Oportuno aclarar, ainda, que a realidade estrutural das organizações demonstra uma descentralização do poder patronal. O exercício do poder diretamente e com exclusividade pelo empreendedor é inviável, mormente se levada em conta a dimensão que a atividade pode tomar, tanto em número de subordinados quanto em ocupação geográfica, ao se multiplicar em diversas agências ou filiais. Assim, justificam-se as delegações de poder que dão origem aos cargos de confiança como gerentes, diretores de áreas específicas, supervisores e afins ${ }^{70}$. Nesses casos, o preposto se substitui ao empregador, recebendo os poderes que a lei confere àquele.

No entanto, deve-se acautelar para que o controle suso mencionado não ultrapasse os limites do profissionalismo e, assim, possibilite uma invasão no território psíquico do trabalhador. Ora, todo direito deve ser praticado sob um

\footnotetext{
${ }^{69}$ CASSAR, Vólia Bonfim. Op. cit.. p. 203.

${ }^{70}$ Valetin Carrion é elucidativo ao dizer que a denominação utilizada nos quadros da empresa não importa, bastando que seja evidenciada a ocupação de cargo de gestão, nos termos do artigo 62, inciso
} 
feixe de ponderação e razoabilidade. É a ratio legis do artigo 187 do Código Civil de 2002, segundo o qual “comete ato ilícito o titular de um direito que, ao exercê-lo, excede manifestamente os limites impostos pelo seu fim econômico e social, pela boa-fé e pelos bons costumes”.

A busca pelo sucesso do empreendimento não pode dar lugar àquilo que a professora Maria Aparecida Alkimin chama de visões utilitaristas e manipuladoras que se desenvolvem através da gestão sob pressão ${ }^{71}$. Este modo de gerir a atividade produtiva inevitavelmente institucionaliza intimidações contra os subordinados e degrada o ambiente de trabalho.

Como se pôde inferir da incursão feita sobre as vítimas mais recorrentes do psicoterror trabalhista, o superior hierárquico adota condutas lesivas contra aqueles que, em alguma esfera, representam um perigo. Esse risco identificado pelo empregador pode decorrer da maior ou menor produtividade do obreiro, da impossibilidade de rescindir o contrato ou até mesmo de características pessoais com as quais o agressor não se adapta. Por essa razão, seus objetivos podem ser múltiplos: provocar um aumento na produção através do temor imposto ao trabalhador; forçar a saída voluntária daquela pessoa do ambiente de trabalho; ou reduzir o papel desta na atividade laborativa, para exaltar o seu. Em suma, seja qual for a finalidade, o assédio moral revela que o poder de mando do empregador deixa de ter aspecto instrumental para propiciar condutas que desconsideram o aspecto humano e digno do subordinado.

É preciso reconhecer, ainda, que o superior hierárquico pode vir a praticar o assédio moral por via oblíqua, isto é, sem manifestar, ele próprio, condutas lesivas contra um de seus subordinados. Comportamentos agressivos podem ser estimulados, visando acirrar a competitividade entre os trabalhadores, carreando, conseqüentemente, o aumento da produtividade. $\mathrm{O}$

II da CLT. (CARRION, Valentin. Comentários à consolidação das leis do trabalho. 34. ed. atual. por Eduardo Carrion. São Paulo: Saraiva, 2009. p. 122).

${ }^{71}$ ALKIMIN, Maria Aparecida. Op. cit. p. 44. 
empregador também pode insuflar o grupo contra um obreiro específico, responsabilizando-o por erros e maus resultados atribuídos a todos os demais ${ }^{72}$.

\subsection{Métodos de assédio}

A humilhação no trabalho pode ocorrer por diversas formas, variáveis segundo os meios socioculturais e profissionais em que se insere ${ }^{73}$, mas sempre marcadas pela depreciação do direito coletivo ao ambiente de trabalho salutar e pela afronta à dignidade humana. São muitas as condutas que cumprem o propósito de afetar a qualidade de vida do trabalhador, mas que consubstanciam a mesma estrutura: o enredamento perverso e a violência moral manifesta.

Num primeiro momento, o contrato de trabalho firma um processo de aproximação entre agressor e assediado. O vínculo de dependência ali travado permite o domínio, muitas vezes perverso, do agressor sobre o trabalhador. Nesse sentido, a posição de superior hierárquico do assediador permite que ele se coloque como indispensável na vida do obreiro, que fica resumido a um estado de conformação e perda da capacidade de oposição. Até aqui, o exercício do poder pelo agressor é legitimado pela própria vítima, que, através do contrato, anui com a subordinação.

Sedimentadas essas linhas inicias, diversas são as condutas que podem acarretar a violência moral no trabalho. A degradação proposital das condições de trabalho é uma delas, que pode se manifestar por diversas vias. A atribuição de tarefas penosas, insalubres ou perigosas contra a vontade da vítima e que

\footnotetext{
${ }^{72}$ Hirigoyen reconheceu essa espécie de violência como “assédio por delegação”, pois insinuações propositais do empregador fazem com que os demais empregados se voltem contra um deles tal qual desejava providenciar o empregador. (HIRIGOYEN, Marie-France. Op. cit. p.273)

${ }^{73}$ Cláudio Couce Menezes cita que, nos setores de produção, a violência é mais direta, podendo ser verbal ou física. Por outro lado, em camadas sociais mais altas, a violência é mais sofisticada. (MENEZES, Cláudio Armando Couce. Assédio moral. Revista Síntese Trabalhista. Porto Alegre, n. 169, ano XV, p. 143).
} 
não eram previstas em contrato cumprem tal objetivo. De igual forma opera a delegação de tarefas que se desviam completamente da função do trabalhador.

O isolamento, por exemplo, consiste no afastamento do trabalhador do convívio coletivo. Com isso, a vítima perde espaço dentro da sistemática da organização, deixando de participar de decisões importantes, de interagir com novidades implementadas e de receber informações acerca da realização dos serviços. Esse objetivo pode ser alcançado através de mudança de estação de trabalho, atribuição de atividades que exigem constantes deslocamentos ou da vedação do uso dos meios de comunicação.

A recusa à comunicação direta é uma das mais cruéis formas de assediar moralmente o trabalhador, porque incute neste a sensação de invisibilidade. É a hipótese do trabalhador que, durante uma reunião, tem sua intervenção respondida com descaso, e até mesmo com absoluto silêncio. Ou ainda, quando seus relatórios de produtividade não são computados para fins estatísticos. A deformação da linguagem também é degradante, pois o tom indiferente ou paradoxal torna mais perceptível a hostilidade e ferocidade que o agressor guarda contra a vítima.

O sarcasmo é a estratégia mais recorrente de que se tem notícia. Insinuações hostis, inconfidências sobre a esfera privada do trabalhador, zombarias e brincadeiras de mau gosto - como, por exemplo, apelidos -, distorcem a imagem que a coletividade guarda daquele sujeito. Uma possível reação da vítima é sempre apontada como excesso de seriedade ante a uma falaciosa demonstração de afeto e intimidade.

Situações de violência mais manifesta também podem ser experimentadas no ambiente de trabalho. Críticas públicas, ameaças verbais de demissão ou cortes salariais são apenas algumas das investidas mais notórias e deliberadas que o agressor pode adotar contra um trabalhador. 


\section{Uma leitura jurisprudencial e legislativa das conseqüências do assédio moral}

\subsection{Conseqüências para o agressor}

O assédio moral, tomado por si só, já traduz uma mazela à organização do trabalho. Seu efeito imediato é a criação de um ambiente laboral tenso, instável e insalubre. Esse cenário, inegavelmente, repercute consideravelmente no ritmo da produção e na lucratividade do empreendimento ${ }^{74}$.

No entanto, o psicoterror não acarreta apenas dissabores econômicos. Há tutela específica que algumas leis estaduais reservam a ele, mas que se limitam a cuidar do tema no âmbito do serviço público estadual ${ }^{75}$. As Assembléias Legislativas dos estados do Rio de Janeiro, São Paulo, Rio Grande do Sul e Mato Grosso aprovaram leis muito semelhantes, que trazem uma definição de assédio moral, vedando-lhe e estipulando as sanções administrativas.

Ademais, dezesseis municípios já aprovaram suas leis contra a coação moral nas relações do serviço público. São eles: Americana/ SP, Campinas/ SP; Cascavel/ PR, Guarulhos/ SP, Iracemápolis/ SP, Jaboticabal/ SP, Natal/ RJ,

\footnotetext{
${ }^{74}$ Sobre o tema, Hirigoyen fala na falta de "tranqüilidade e paz de espírito” para o curso normal da atividade. (HIRIGOYEN. Marie-France. Op. cit. 321).

${ }^{75}$ Muito semelhante, os projetos de leis federais $n^{\circ} 4.591 / 01$ e $n^{\circ} 5.972 / 01$ propõem reforma na lei $n^{\circ}$ 8.112/91, o Regime Jurídico Único, para combater o assédio moral nas relações hierárquicas do serviço público federal. Se aprovada, a reforma definiria e vedaria, expressamente, o assédio moral, disciplinando o processo administrativo para apuração da prática e a punição cabível. Há também o projeto de lei federal $n^{\circ} 2.369$, apresentado originalmente no ano de 2003, para disciplinar o assédio moral nas relações privadas de trabalho, no entanto, encontra-se paralisado desde 2007. A proposta define assédio moral como toda conduta, dolosa ou não, que atente contra dignidade ou direitos do trabalhador, ou que afete sua higidez física ou mental, ou, ainda, que comprometa a sua carreira profissional. Disciplina ainda a questão da indenização devida pelo empregador, fixando um valor mínimo, e traz regras de fiscalização.
} 
Porto Alegre/ RS, São Gabriel do Oeste/ MS, São Paulo/ SP, Sidrôlandia/ MS, Ubatuba/ SP, Araraquara/ SP, Amparo/ SP, Santa Maria/ RS e Contagem/ MG. Sem que se pretenda desmerecer o pioneirismo das leis citadas, é preciso reconhecer que têm alcance muito restrito, já que só se aplicam aos servidores públicos. E não poderia ser diferente, pois é competência privativa da União legislar sobre direito do trabalho, consoante inciso I do artigo 22 da Constituição Federal. Mas nem por isso o assédio moral é matéria desamparada. Previsões esparsas do ordenamento cumprem bem a função de tutelar a relação de violência em outras esferas, conforme se pode inferir da tendência jurisprudencial sobre o tema.

Destarte, aquele que assedia moralmente outrem no ambiente de trabalho, não sai impune. Nossos tribunais vêm procurando sancionar sua conduta dentro e fora do contrato de trabalho, através de soluções que são encontradas na CLT e no Código Civil.

Quando o agressor reveste a forma do empregador, a primeira repercussão do assédio moral que se pode encontrar na jurisprudência é o reconhecimento da dispensa indireta, do artigo 483 da CLT, e que já averiguamos alhures. São recorrentes as decisões condenatórias do empregador a perder a mão de obra, mas arcando com todas as verbas rescisórias, tal qual se tivesse a dispensado sem justo motivo ${ }^{76}$.

76 EMENTA: INDENIZAÇÃO POR DANO MORAL. ASSÉDIO. RESCISÃO INDIRETA. IMEDIATIDADE. Comprovada a prática de atos pela preposta da Empresa, que exorbitaram o poder discricionário do empregador, configurando o assédio, traduzido pela violência psicológica, sistemática e freqüente contra a empregada, causando-lhe desequilíbrio emocional e dor íntima, reconhece-se a rescisão indireta do contrato de trabalho decorrente de ofensa moral e a obrigação de indenizar, constitucionalmente assegurada. Nesse sentido, não se pode acolher a tese patronal de ausência de imediatidade, porquanto as situações de assédio moral relatadas causaram angústia na obreira, pouco a pouco, não se podendo entender que houve perdão tácito, só por não ter ela se insurgido, quando da primeira vez em que se sentiu ofendida. (TRT3, RO 00809-2007-131-03-00-6, Rel. Juiz Irapuan de Oliveira Teixeira Lyra, Minais Gerais, 14 nov. 2007)

RESCISÃO INDIRETA. ALTERAÇÃO DO LOCAL DE TRABALHO E RECUSA EM COMPLEMENTAR O VALE-TRANSPORTE. A recusa em assumir o acréscimo necessário de mais duas passagens de ida e volta, após alteração do posto de trabalho do empregado, ocasionando o estrangulamento econômico e a inviabilização do cumprimento do contrato, tudo no afã de pressionar o trabalhador a abandonar os serviços ou pedir demissão, constitui forma velada de assédio moral e psicológico. Justifica-se no contexto, a rescisão indireta por culpa patronal, com espeque no artigo 483, 
Observa-se que não demanda maiores digressões o processo de enquadramento do ato violento - nas modalidades indicadas a título de ilustração no capítulo 3 -, com as previsões do artigo citado. Sendo certo que a finalidade motriz do assédio moral é impor à vítima uma aflição tal que, querendo ou não, torna insuportável a permanência desta no trabalho ${ }^{77}$, fato é que o empregador adotou uma maneira oblíqua e dissimulada de despedir o assediado, nas palavras de José Prunes ${ }^{78}$.

O fato da prática do assédio partir de superior hierárquico, que não seja o empregador direto, não desnatura a rescisão indireta. A uma, porque se trata de uma conseqüência dos poderes que o empregador transferiu ao seu gerente - conforme nomenclatura utilizada pelo artigo 62, inciso II da CLT -, autorizando que este lhe substitua, de modo que, quando o gerente age, está manifestando a vontade do próprio empregador, por delegação. A duas, devido à responsabilidade objetiva que o empregador assume na direção da atividade de empresa. A culpa dele, neste caso, é fruto de uma presunção juris et de jure.

É bem verdade, como dito antes, que a conduta assediante pode ser enquadrada dentre as hipóteses do artigo 483 da CLT com relativa facilidade. Mesmo assim, tramita no Congresso Nacional o projeto de lei federal $\mathrm{n}^{\circ}$ 5.970/01 ${ }^{79}$, que pretende explicitar, no texto da consolidação, o assédio moral como causa de despedida indireta.

d, da CLT, tornando-se credor o demandante, das verbas rescisórias e FGTS, além das multas dos artigos 467 e 477 da CLT. Recurso obreiro a que se dá provimento. (TRT2, RO 00457-2008-038-0200-1, Relator Juiz Ricardo Artur Costa e Trigueiros, São Paulo, 03 jul. 2009).

${ }^{77}$ É o que se denota das seguintes razões de voto: "Finalmente, estranho o desejo do reclamante de ser reintegrado ao emprego. Se o ambiente de trabalho realmente fosse hostil à sua pessoa e o tivesse sujeitado a sucessivas perseguições e humilhações, o normal seria querer se desligar dali. Poderia ter requerido rescisão indireta, ao invés de reintegração. Isso porque os institutos assédio moral e reintegração são incompatíveis”. (TRT3, RO 00105-2004-089-03-00-0, Rel. Juíza Olívia Figueiredo Pinto Coelho, Minas Gerais, 28 jul. 2004).

${ }^{78}$ PRUNES, José Luiz Ferreira. Justa causa e despedida indireta. Curitiba: Juruá, 1994. p. 228.

${ }^{79}$ Projeto de lei federal $n^{0} 5.970 / 2001$

O Congresso Nacional decreta:

Artigo $1^{\circ}$ - O art. 483 do Decreto-Lei n. ${ }^{\circ}$ 5.452, de $1^{\circ}$ de maio de 1943 - Consolidação das Leis do Trabalho, passa a vigorar acrescido da alínea "g", com a seguinte redação:

"Art. 483... 
Na mesma medida, o trabalhador assediador também é responsabilizado pelos danos causados por sua conduta, através da submissão ao poder disciplinar do empregador. Afinal, o empregado, ao atentar contra a integridade psicofísica de colateral ou subalterno na hierarquia interna da empresa, incorre em falta tão grave que, dependendo da forma como se desenvolve, chega a ser imperiosa a rescisão do seu contrato por justa causa, nos termos do artigo 482 da CLT.

Numa de suas manifestações mais recorrentes na praxe trabalhista, o assédio moral horizontal ocorre por meio de ofensas diretas e acusações. É precisamente esta a hipótese aventada nas alíneas “j” e “k” do artigo precitado $^{80}$. Tais comportamentos tendem a degradar o ambiente de trabalho e, por isso, tornam insustentável a preservação do vínculo de emprego. Não se pode cogitar da preservação de um laço pautado na fidúcia e boa-fé quando uma das partes agride, sistematicamente, os direitos da personalidade dos demais integrantes da atividade empresarial.

De forma mais abrangente, é possível ainda adequar o comportamento do empregado agressor na previsão de mau procedimento da alínea “b” do artigo 482. Não há dúvidas que este trabalhador infringe o dever social de boa

g) praticar o empregador ou seus prepostos, contra ele, coação moral, através de atos ou expressões que tenham por objetivo ou efeito atingir sua dignidade e/ou criar condições de trabalho humilhantes ou degradantes, abusando da autoridade que lhe conferem suas funções”.

Artigo $2^{\circ}$ - O $\S 3^{\circ}$ do art. 483 do Decreto-Lei n. ${ }^{\circ}$ 5.452, de $1^{\circ}$ de maio de 1943 - Consolidação das Leis do Trabalho, passa a vigorar com a seguinte redação:

"§ 3 Nas hipóteses das letras d, g e h, poderá o empregado pleitear a rescisão de seu contrato e o pagamento das respectivas indenizações, permanecendo ou não no serviço até final decisão do processo. (NR)"

Artigo $3^{\circ}$ - Acrescente-se o art. 484-A ao Decreto-Lei n. ${ }^{\circ}$ 5.452, de $1^{\circ}$ de maio de 1943 - Consolidação das Leis do Trabalho, com a seguinte redação:

"Art. 484 - A Se a rescisão do contrato de trabalho foi motivada pela prática de coação moral do empregador ou de seus prepostos contra o trabalhador, o juiz aumentará, pelo dobro, a indenização devida em caso de culpa exclusiva do empregador."

Artigo $4^{\circ}$ - Esta Lei entra em vigor na data de sua publicação.

${ }^{80}$ A doutrina majoritária segue firme em entender que o legislador, ao referir-se aos atos lesivos da honra e boa fama, tratava da calúnia, da injúria e da difamação. (CARRION, Valentin. Op. cit. p. 384). Diverge desse entendimento, porém, a professora e juíza Vólia Bonfim Cassado, para quem os tipos penais citados têm contornos que o Direito do Trabalho não precisa obedecer. Com efeito, para ela, qualquer ato que venha a macular a honra e boa fama de outrem dá ensejo à justa causa. (CASSAR, Vólia Bonfim. Op. cit. p. 871). 
conduta, que a professora Vólia Cassar $^{81}$ desdobra em polidez, educação e paciência. Indo além, é preciso recordar que não se trata de uma regra de esmero pessoal apenas, mas de dever contratual, já que ser diligente e agir com boa fé em relação ao empregador, superior hierárquico e colegas de trabalho é uma obrigação anexa ao pacto de trabalho.

Por outro lado, deve-se lembrar que o assediador também responde civilmente pelo ato ilícito praticado. Ora, como visto antes, o artigo 187 do Código Civil é claro ao considerar o abuso no exercício de um poder ato ilícito. Portanto, aquele que se vale das relações de poder inerentes ao contrato de trabalho para subjugar outro responde pelos danos morais e materiais a que deu causa.

O conjunto de julgados apreciados também não permite que se negue que o assediador provoca um dano moral incomensurável a sua vítima. Um conceito eficiente de dano moral é fornecido por João Lima Teixeira ${ }^{82}$, para quem representa sofrimento provocado por ato ilícito que molesta direitos. Já restou bastante sedimentado que o assédio moral se concretiza através de seqüenciais mutilações a direitos, ora trabalhistas, ora da personalidade ${ }^{83}$. A vítima experimenta, ao longo de todo o processo violento, um sentimento de dor e humilhação que não resulta de perdas pecuniárias.

A essência do homem está na sua força de trabalho. É aí que ele legitima-se com indivíduo da sociedade. Quando esse aspecto da sua vida é afetado, como ocorre no caso do assédio, em que é expurgado do ambiente de trabalho, resta também mutilada a moral do empregado. Assim, a

\footnotetext{
${ }^{81}$ Ibid. p. 853.

${ }^{82}$ TEIXEIRA, João de Lima; MARANHÃO, Délio; VIANNA SEGRADAS; SÜSSEKIND, Arnaldo. Op. cit. p. 629.

${ }^{83}$ ASSÉDIO MORAL - O empregador tem o direito de exigir dos seus empregados o cumprimento satisfatório de suas obrigações contratuais. Mas quando a sua conduta ultrapassa os limites eticomorais exigíveis, expondo o trabalhador a reiteradas situações vexatórias, com o intuito de puni-lo pelo não alcance de meta e ao mesmo tempo forçá-lo ao alcance sempre maior de produtividade, o assédio moral resta configurado, em afronta ao princípio fundamental da dignidade da pessoa humana (art. $1^{\circ}$, III da C.F.), atraindo o direito à indenização correlata”. Grifo meu. (TRT3, RO 00099-2005- 111-0300-8, Rel. Juíza Alves Horta, Minas Gerais, 22 out. 2005).
} 
responsabilização do causador é necessária, primeiro, para compensar a vítima pelo mal que lhe foi injustamente imputado. Depois, para punir o ofensor, bem como servir de exemplo à sociedade.

A doutrina cita como leading case da reparação do dano moral advindo do assédio o seguinte aresto:

\begin{abstract}
Assédio moral - Contrato de inação - indenização por dano moral - A tortura psicológica, destinada a golpear a auto-estima do empregado, visando forçar sua demissão ou apressar sua dispensa através de métodos que resultem em sobrecarregar o empregado de tarefas inúteis, sonegar-lhe informações e fingir que não o vê, resultam em assédio moral, cujo efeito é o direito à indenização por dano moral, porque ultrapassa o âmbito profissional, eis que minam a saúde física e mental da vítima e corrói a sua auto-estima. No caso dos autos, o assédio foi além, porque a empresa transformou o contrato de atividade em contrato de inação, quebrando o caráter sinalagmático do contrato de trabalho e, por conseqüência, descumprindo a sua principal obrigação que é a de fornecer trabalho, fonte de dignidade do empregado $^{84}$.
\end{abstract}

Jurisprudência e doutrina, hoje, não afinam no mesmo diapasão sobre a responsabilidade do empregador quanto ao dano moral provocado por um empregado ao seu par. Por muito tempo, advogou-se a tese que o empregador, devido seu papel de gestor de todo o empreendimento, responderia pelos danos advindos do assédio moral, mesmo que não seja ele o agressor, tendo em vista a responsabilidade civil objetiva consagrada no parágrafo único do artigo 927 do Diploma Civil vigente.

Com isso, ficaria incutido no empregador não só o dever de se furtar de assediar, mas de zelar para que tais práticas jamais sejam adotadas no seu empreendimento, por quem quer que seja. Ato contínuo, o empregador poderia se valer da previsão do artigo 934 do mesmo diploma para pleitear o ressarcimento do quantum que desembolsou a título de reparação. E para tanto, é possível socorrer-se do $\S 1^{\circ}$ artigo 462 da CLT, cujo texto autoriza os descontos na paga do empregado provadamente culpado.

\footnotetext{
${ }^{84}$ TRT17, RO 1315.2000.00.17.00.1, Rel. Juíza Sonia das Dores Dionízio, Espírito Santo, 20 ago. 2002.
} 
No entanto, recente decisão da colenda $2^{\mathrm{a}}$ Turma do Tribunal Superior do Trabalho ${ }^{85}$ entendeu que a empresa não se responsabilizaria pela prática de discriminação desferida por um empregado a outro funcionário, já que o empregador, no caso, não tinha conhecimento do fato. Dada a novidade da posição, ainda não há manifestação na doutrina sobre o tema.

De maneira embrionária, o Poder Legislativo vem investigando a possibilidade do agressor responder ainda na seara penal. Isso porque não se duvida que o assédio moral lesiona bens da vida tutelados pelo direito penal. São muitos os enquadramentos que podemos fazer para confirmar que a violência moral consubstancia um ato deveras criminoso. É possível considerar que houve um dos crimes contra a honra, previstos nos artigos 138 a 140 do Código Penal. Algumas condutas assediantes também podem ser consideradas crime de periclitação da vida e da saúde, previsto no artigo 136 e comumente conhecido como crime de maus-tratos. Uma terceira hipótese de tipificação do assédio moral está no artigo 146 do CP, que disciplina o constrangimento ilegal.

No entanto, tem-se notícia de projetos de lei federal ${ }^{86}$ que visam, através de reformas no diploma penal, criminalizar especificamente o assédio moral, ou seja, criar um tipo penal novo, para que não seja necessário tomar por empréstimo outras figuras. Em suma, pretendem tipificar o assédio moral

\footnotetext{
${ }^{85}$ RECURSO DE REVISTA. DANOS MORAIS. CARACTERIZAÇÃO. O eg. TRT, soberano na análise da prova, consignou de forma expressa que os atos discriminatórios praticados contra o autor não podem ser imputados à entidade empresarial, na medida em que não restou comprovada sua participação nos mesmos. Com efeito, consta expressamente da v. decisão regional o entendimento de que a lei civil, quando fala da responsabilidade da empresa por atos de seus prepostos (art. 1.521 do Código Civil), refere-se, evidentemente, àqueles assumidos em seu nome, não sendo esta a hipótese em comento. Ante a ausência da prova quanto à culpa do empregador, é de se reconhecer ter sido atribuída a correta subsunção da descrição dos fatos às normas pertinentes. Recurso de revista não conhecido. DANO MORAL. VALOR DA INDENIZAÇÃO. Uma vez não conhecido o apelo relativamente ao item anterior, resta prejudicado o exame do tema recursal, porquanto mantida a $\mathrm{v}$. decisão regional que excluiu da condenação o pagamento da indenização por danos morais. Recurso de revista não conhecido. Grifo meu. (TST, RR 20024.2003.001.09.00-3, Rel. Min. Renato de Lacerda Paiva, Brasília, 23. set. 2009).

${ }^{86}$ Cf. Projeto de Lei Federal n 4.742/ 01 e 5.971/ 01.
} 
como crime, através da inserção de um novo artigo no diploma penal, que poderá contar com uma das duas redações:

\footnotetext{
Depreciar, de qualquer forma, reiteradamente a imagem ou o desempenho do servidor público ou empregado, em razão de subordinação hierárquica funcional ou laboral, sem justa causa, ou tratá-lo com rigor excessivo, colocando em risco ou afetando sua saúde física e psíquica.

$\mathrm{Ou}$,

Coagir moralmente empregado no ambiente de trabalho, através de atos ou expressões que tenham por objeto atingir a dignidade ou criar condições de trabalho humilhantes ou degradantes, abusando da autoridade conferida pela posição hierárquica.
}

\subsection{Conseqüências para o assediado}

Como já foi visto até aqui, o assédio moral ataca a vítima naquilo que lhe dignifica, que é sua força de trabalho e capacidade produtiva. A violência dirigida a essa específica área de sua vida se irradia para todas as demais searas, isto é, afeta-lhe no campo profissional, social e, na pior das hipóteses, pode ceifar-lhe a saúde.

Não se pode ignorar que o homem, pela simples razão de sê-lo e, ao contrário das máquinas, tem seu desempenho influenciado, em qualquer área a que se dedique, por fatores externos, como pessoas, ambientes e fatos. Os níveis de produtividade que um obreiro alcança dependem, e muito, das condições em que seu trabalho é exercido. A satisfação pessoal dita o ritmo do desempenho e permite um prognóstico dos resultados que se pode esperar, na medida em que depende disto o grau de zelo e diligência com que o profissional vai lidar com suas incumbências.

Por tal ótica, se, no ambiente de trabalho, o trabalhador encontra um clima ameno, de profissionalismo e cooperação, terá o incentivo necessário para se dedicar ao empreendimento, estreitando seu vínculo com seus pares, superiores e também com a imagem e ideologia da própria instituição. Em 
outras palavras, o trabalhador vai se identificar e engajar na atividade, o que garante a melhoria dos resultados de sua produção.

A contrário senso, ao ser inserido num ambiente de trabalho perverso, violento e que tende a minar sua imagem, honra e boa fama - em suma, valores subjetivos, que compõem sua personalidade e o individualizam -, o foco do trabalhador é desviado. É natural que, como reação aos traumas vividos no local de labor, o trabalhador imponha certo distanciamento entre ele e a atividade da empresa, podendo chegar ao ponto desta lhe despertar profundo mal estar e repugnância. Com isso, obviamente, surge um comportamento improdutivo.

Mais grave ainda - por antecipar uma disfunção orgânica -, é o efeito inverso. Em alguns casos, o trabalhador acuado, seja pelo medo do desemprego ou na tentativa de resgatar sua reputação, pode vir a concentrar esforços desmedidos na atividade laborativa. Isto é, uma dedicação demasiada e igualmente desgastante pode ser aventada por ele como a solução para vencer a violência sofrida e se reafirmar como profissional. Numa lógica meramente capitalista este cenário parece positivo, mas apenas a curto prazo. O ritmo acelerado demais não será mantido por todo o tempo, e, em algum momento, dará azo ao absenteísmo, para recomposição da saúde que se perdeu durante o período de hiperatividade.

Fato é que as oscilações supra citadas na produtividade do trabalhador não poderão ser causa de descontos salariais, por vedação expressa do artigo $7^{\circ}$, inciso VI da Carta Política. No entanto, o empregador malsinado poderá se valer de tal expediente para fundamentar uma rescisão contratual por justa causa.

É seguro afirmar que o assédio moral repercute, ainda, na saúde do obreiro. A jurisprudência estudada segue firme em reconhecer que o assédio no 
ambiente de trabalho provoca o adoecimento clínico do trabalhador ${ }^{87}$, que pode vir a convergir para uma redução, ainda que transitória, da sua capacidade laborativa.

O trabalhador não fica apático aos atos abusivos do assediador, por mais que possa quedar-se inerte. A inércia, aqui, se relaciona muito mais com necessidade de se manter no emprego a qualquer custo do que com a indiferença. Por isso, a sistematização dos ataques vai convergir, ao menos, para um estado de estresse, manifestado através de alteração da libido, cansaço, irritabilidade, palpitações, tremores, distúrbios do sono, hipertensão, distúrbios digestivos e dores generalizadas, por exemplo. A medicina considera que esse quadro é uma reação do organismo à hiperestimulação e à tentativa de $\operatorname{adaptação~}^{88}$.

87 “(...) o assédio moral envolve uma situação prolongada no tempo, que se configura a partir de atitudes reiteradas de desrespeito, desprezo e humilhações, não sendo assim constituído a partir de um único ato específico, bem como de que - a imediaticidade na rescisão indireta tem de ser claramente atenuada, uma vez que a reação obreira tende a ser muito contingenciada por seu estado de subordinação e pela própria necessidade de preservar o vínculo, que lhe garante o sustento e de sua família-, sendo que o ajuizamento de demandas anteriores, a legalidade do encerramento de agências no exterior ou a permanência do vínculo empregatício até determinada data, por si só, não interferem nem excluem o abalo emocional comprovado nos autos, e, ainda, de que os elementos probatórios evidenciam que embora a empregada sofresse tratamento discriminatório, procurava lidar com as dificuldades do ambiente de trabalho, todavia, sem sucesso. Acresça-se que, à fl. 513, noticia o v. acórdão impugnado ter a reclamante se submetido a cuidados profissionais, consignando o Juízo a quo haver nos autos atestados comprovando o estado de stress intenso, estafa e depressão-, restando informado pelo médico que a autora -Apresentava na ocasião intensas manifestações depressivoansiosas, por força de inúmeras condições adversas havidas em seu ambiente de trabalho". (TST, RR1044/2003-039-02-00.6, Relator Ministro Aloysio Corrêa da Veiga, Brasília, 19 ago. 2009).

“Analisando-se a prova oral. produzida, verifica-se que os empregados da reclamada, incluído o reclamante, realmente eram tratados de forma ofensiva e humilhante e que a testemunha presenciou o autor ser xingado inúmeras vezes pelo presidente da empresa. Tal tratamento, além de causar absoluto desconforto emocional e moral, eleva o nível de stress do trabalhador, acabando com sua tranqüilidade no ambiente de trabalho. Esta prática perpetrada pela reclamada, demonstra quão desimportantes são para ela os valores íntimos de seus empregados”. (TST, AIRR-211/2006-343-01-40.8, Relator Min. Rosa Maria Weber Candiota da Rosa, Brasília, 25 jun. 2009)

"Tenho, pois, por demonstrado nos autos que os atos praticados pelo empregador consubstanciaram assédio moral, atingindo atributos de personalidade da autora que teve desencadeamento de doença associada ao estresse e à pressão sofridos no trabalho, o que está demonstrado tecnicamente pela profissional médica que a está tratando. Caracterizado o assédio moral no trabalho, a culpa e o nexo causal entre a conduta do empregador e a as conseqüências suportadas pela autora atingindo-a em atributos da sua personalidade (imagem, honra, dignidade no trabalho), impõe-se, à luz do disposto nos artigos 186 do CCB/2002, e 5², incisos V e X, da Constituição Federal”. (TRT4, RO 00149-2005-02504-00-6, Rel. Juiz Milton Varela Dutra, Rio Grande do Sul, 24 jun. 2007)

${ }^{88}$ HIRIGOYEN, Marie-France. Op. Cit. p. 215. 
O estresse originado do assédio moral vai se agravando com a incitação de sentimentos de humilhação, impotência e de que não se está vivendo uma situação normal. A recuperação é impossível enquanto persistir a situação violenta, por mais que os sintomas sejam simples e de fácil tratamento.

Essa persistência do assédio faz com que o quadro clínico, até então de mero estresse, evolua para uma depressão mais preocupante. A depressão tem uma conotação negativa na sociedade, sendo considerada fraqueza. Por isso, são reduzidas as chances da vítima buscar apoio médico, dando azo ao surgimento de muitas outras enfermidades, em um desenvolvimento rápido e grave.

Não se questiona mais que se trata, efetivamente, de uma doença ${ }^{89}$, constando do rol do CID 10 - Classificação Estatística Internacional de Doenças e Problemas Relacionados à Saúde elaborado pela Organização Mundial de Saúde. Estudos já comprovam que, hoje, o transtorno depressivo é uma das maiores causas de incapacitação do mundo ${ }^{90}$, vez que pode piorar o

\footnotetext{
${ }^{89}$ Segundo a Biblioteca Virtual em Saúde organizada pelo Ministério da Saúde, a depressão é uma doença. Há uma série de evidências que mostram alterações químicas no cérebro do indivíduo deprimido, principalmente com relação aos neurotransmissores (serotonina, noradrenalina e, em menor proporção, dopamina), substâncias que transmitem impulsos nervosos entre as células. (Disponível em <http://bvsms.saude.gov.br/html/pt/dicas/76depressao.html>. Acesso em 30 set. 2009).

${ }^{90}$ A jurisprudência já não apresenta resistência a isso: REVISIONAL - APOSENTADORIA POR INVALIDEZ -DEPRESSÃO GRAVE E INCURÁVEL - INCAPACITAÇÃO - APOSENTADORIA COM PROVENTOS INTEGRAIS - HIPÓTESE PREVISTA NA LEI MUNICIPAL - RECURSO PROVIDO. (TJMG, Processo 2004.009529-2, Rel. Des. Paulo Alfeu Puccinelli, Minas Gerais, 10 nov. 2004).

"PREVIDENCIÁRIO - APOSENTADORIA POR INVALIDEZ - CANCELAMENTO. I - As razões expendidas no recurso não abalam os fundamentos da decisão recorrida, que merece ser mantida; II - A cessação dos benefícios da aposentadoria, de acordo com o art 47 da Lei $n^{\circ}$ 8.213/91, depende da recuperação da capacidade laborativa; III - O laudo pericial de f. 44/45, a que se reporta o Apelante, como bem ressaltado na sentença, apenas conclui que o Réu foi aposentado por depressão neurótica, sendo doença afeta à área psiquiátria, não havendo afirmação categórica de que o Apelado se encontra

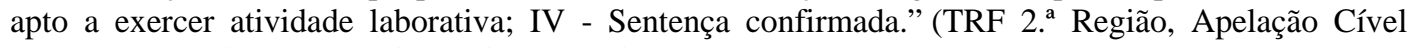
284200, Rel. Juiz Arnaldo Lima, Rio de Janeiro, 21 mar. 2003)

"PREVIDENCIARIO.APOSENTADORIA POR INVALIDEZ. INCAPACIDADE EXISTENTE A EPOCA DO CANCELAMENTO DO AUXILIO-DOENÇA.1. Não tendo a autarquia previdenciária, em nenhum momento, manifestado impugnação a qualquer dos laudos apresentados, desacolhe-se a pretensão, só agora alegada, de nulificar a sentença, por não ter o apelado atendido a intimação para submeter-se a exames periciais. 2. Comprovada por perícia médico-judicial que a autora padecia de “depressão neurótica”, moléstia que a incapacita para o trabalho e convívio em empregos coletivos, e de reconhecer-se o direito a aposentadoria por invalidez, desde o cancelamento do auxilio-doença,
} 
curso de várias outras debilidades físicas ou desencadear novas enfermidades. Por exemplo, os riscos de doenças circulatórias e do coração são potencializados em pessoas deprimidas. Aqueles que foram vítimas de infarto do miocárdio e que têm depressão após o problema também se tornam mais vulneráveis a novos ataques cardíacos, incapacitação e até à morte súbita. Da mesma forma, a depressão durante a gravidez é uma das principais causas nãoreconhecidas dos partos prematuros, que podem levar à morte e a graves doenças infantis, segundo um estudo do Instituto de Psiquiatria do King's College de Londres ${ }^{91}$.

Há, ainda, uma tendência embrionária na jurisprudência, alinhada a um crescente movimento doutrinário, sobre a possibilidade de o assédio moral ser considerado causa de acidente de trabalho. O egrégio TST foi instado sobre o tema em um Agravo de Instrumento em sede de Recurso de Revista ${ }^{92}$, sendo que lhe foi negado seguimento sem enfrentamento do mérito. Por outro lado, os Tribunais Regionais vêm se movimentando bastante nessa esteira. Nesse sentido, é emblemático o acórdão do colendo $23^{\circ} \mathrm{TRT}^{93}$, cujas razões merecem detida análise.

porque o mal remonta aquela época. 3. Apelação improvida.” (TRF 4. ${ }^{a}$ Região, Apelação Cível 9104262077, Rel. Juiz Ronaldo Luiz Ponzi, Rio Grande do Sul, 22 nov. 1994).

91 Depressão pode causar parto prematuro. Disponível em <http://g1.globo.com/Noticias/Ciencia/0,,MRP17684-5603,00.html>. Acesso em 24. set. 2009.

${ }^{92}$ Cf. TST, AIRR-280/2007-009-23-40.7, Relator Min. Renato de Lacerda Paiva, Brasília, 27 mai. 2009.

${ }^{93}$ LITISPENDÊNCIA E CARÊNCIA DE AÇÃO (AUSÊNCIA DE INTERESSE PROCESSUAL E IMPOSSIBILIDADE JURÍDICA DO PEDIDO RELATIVO AO DANO MORAL E MATERIAL). NÃO CARACTERIZAÇÃO. 1. Para configurar a litispendência é necessária a identidade de partes, de pedido e da causa de pedir. No caso dos autos, não se caracteriza a litispendência porquanto na demanda ajuizada da Justiça Comum pela Autora buscou-se indenização em razão dos danos a sua honra e imagem, bem assim em face de outros danos derivados, os quais refletiram em sua filha supérstite, enquanto na presente ação busca a Reclamante a indenização em face de alegado acidente de trabalho (doença ocupacional) originado, além dos fatos narrados na demanda civil, de atos ilícitos continuados (assédio moral) praticadas por prepostos do Empregador, os quais supostamente concorreram para a incapacidade laboral da Reclamante. Deste modo, não há que se falar em litispendência, uma vez que se tratam de pedidos assentados em fatos diversos. 2. Pela mesma razão, não prospera a argüição de ausência interesse processual. 3. No que diz respeito a impossibilidade jurídica do pedido, também não se sustenta a irresignação da Reclamada já que encontram respaldo legal. Argüição patronal que se rejeita. (omissis). 'DOENÇA DO TRABALHO. NEXO CAUSAL CARACTERIZADO. INDENIZAÇÕES POR DANOS MATERIAIS E MAORAIS DEVIDAS. A doença ocupacional equipara-se ao acidente do trabalho (arts. 19 e 20 da Lei 8.213/91), de modo que a 
O artigo 19 da lei $n^{\circ}$ 8.213/ 91 nos confere um conceito de acidente do trabalho como aquele que ocorre pelo exercício do trabalho a serviço da empresa ou pelo exercício do trabalho dos segurados especiais, provocando lesão corporal ou perturbação funcional que cause a morte ou a perda ou redução da capacidade laborativa, seja permanente ou temporária. A doutrina aponta que a citada norma alude à ocorrência de um evento danoso único, involuntário e cujo nexo causal seja facilmente reconhecido ${ }^{94}$. Contudo, essa não é a única hipótese.

As razões do aresto citado recordam que, no artigo 20, duas “entidades mórbidas”, nos termos da lei, são equiparadas ao acidente de trabalho. Tratase, de um lado, da doença profissional, que é aquela “desencadeada pelo exercício do trabalho peculiar a determinada atividade e constante da respectiva relação elaborada pelo Ministério do Trabalho e da Previdência Social”. De outro, da doença do trabalho, definida como “desencadeada em função de condições especiais em que o trabalho é realizado e com ele se relacione diretamente”.

\footnotetext{
obrigação de reparação pelos danos dela provenientes decorre da culpa patronal, a qual deve ser provada pela Autora, já que se trata de fato constitutivo do seu direito. Evidenciado pelo conjunto probatório que a Reclamante desenvolveu distúrbio de origem física e psíquica (pressão alta severa e transtornos psiquiátricos) em decorrência de ato ilícito praticado pela Reclamada (assédio moral), que provocaram a sua incapacidade para o exercício do trabalho, há que se reconhecer seu direito às indenizações por danos materiais e morais, com supedâneo no inciso XXVIII do art. $7^{\circ}$ da Constituição Federal. Recurso Ordinário do Reclamado ao qual se nega provimento.' (omissis) 'RECURSO DE AMBAS AS PARTES. DANO MATERIAL. PENSÃO DECORRENTE DE ATO ILÍCITO E PENSÃO DO INSS. CUMULAÇÃO. TERMO INICIAL E FINAL DA CONDENAÇÃO. 1. A pensão custeada pelo INSS não se confunde com a pensão decorrente da responsabilidade civil arcada pela Reclamada, pois diferem quanto à origem e quanto à finalidade. A pensão decorrente da responsabilidade civil origina-se do Código Civil e tem como finalidade ressarcir a vítima, em razão de ato ilícito, pelos danos materiais sofridos no que diz respeito aos lucros cessantes, enquanto que a pensão custeada pelo INSS tem origem na legislação previdenciária, servindo como um seguro social, custeado pelos trabalhadores, empregadores e pela sociedade, contra acidentes sofridos pelo trabalhador. Dessa forma, deve a Empregadora responder integralmente pela parte que lhe cabe (lucros cessantes), sem que essa circunstância importe em enriquecimento ilícito da Obreira. 2. De outro norte, a condenação da Ré ao pagamento da pensão, arbitrada a título de lucros cessantes é devida desde o primeiro afastamento, sempre após o $15^{\circ}$ dia de afastamento, acrescida de juros e correção. Recurso Patronal ao qual se nega provimento e Recurso da Reclamante ao qual se dá provimento.' Grifo meu. (TRT23, RO - 01040.2007.003.23.00-7, Rel. Des. Liz Alcântara, Mato Grosso, 29 out. 2008).

${ }_{94}$ CECILIA, Silvana Louzada Lamattina. Responsabilidade do empregador por danos à saúde do trabalhador. São Paulo: LTr, 2008. p. 45.
} 
É nesta segunda classe, de doenças profissionais, que o julgado enquadra o adoecimento provocado pelo assédio moral. A doença do trabalho, ou mesopatia, não tem nexo exclusivo com uma profissão ou atividade específica. Na verdade, ela decorre da forma como o trabalho é exercido. Por isso, é totalmente condizente com a realidade do assédio moral, já que este é uma forma violenta de gestão e organização laboral ${ }^{95}$. As condutas do agressor representam mal suficiente para, através das manifestações físicas dos distúrbios psicológicos, tornar a vítima inapta para o trabalho. Daí resulta a caracterização do acidente de trabalho.

Noutro passo, a demonstração dos elementos culpa ${ }^{96}$ e nexo causal ${ }^{97}$, exigíveis para a responsabilização do empregador pelo acidente de trabalho, também não têm fugido à análise dos tribunais. E, uma vez reconhecido o acidente de trabalho por equiparação, o trabalhador que sofre abalo moral com

\footnotetext{
${ }^{95}$ É a fundamentação do acórdão em tela no seguinte sentido: “Ora, denoto que o ambiente de trabalho ao qual estava submetida a Reclamante era hostil, o que imprimia a Autora constante sofrimento, fato potencialmente ofensivo a sua condição já amplamente fragilidade, contribuindo indubitavelmente para o comprometimento de sua saúde, em seus mais variados aspectos, e conseqüente para a incapacidade laboral”.

${ }^{96}$ RECURSO ORDINÁRIO DA RECLAMANTE DOENÇA OCUPACIONAL. DANOS MORAIS E MATERIAIS. ESTABILIDADE ACIDENTÁRIA. ÔNUS DA PROVA. Para que se determine a responsabilidade civil do Empregador em decorrência de dano sofrido pelo Obreiro se faz necessária a constatação do acidente do trabalho - no caso a doença ocupacional, a culpa patronal, bem como o nexo causal entre a lesão e a atividade laboral. Não estando provado cabalmente qualquer desses elementos, não há que se falar em indenização por danos morais e materiais. No caso, a Reclamante não comprovou a existências da lesão noticiada e a alegada perda da capacidade laborativa. Dessa forma, inviável o pleito de indenização por danos morais e materiais e os demais pedidos decorrentes da pretensa estabilidade acidentária. Recurso Ordinário da Reclamante ao qual se nega provimento. (TRT23, RO - 01815.2007.051.23.00-8, Rel. Des. Luiz Alcântara, Mato Grosso, 05 nov. 2008).

97 “O Reclamante insurge-se contra a v. sentença, que não reconheceu o nexo causal entre a doença de que padece com as atividades realizadas na Ré. Argumenta que foi acometido por doença relacionada com a sua atividade laboral, por culpa da Ré; que ainda que exista causa preexistente, as perseguições sofridas pelo empregado na empresa e a pressão por produtividade concorreram para o dano e, por fim, que a sua dispensa é nula porque estava doente. Razão não lhe assiste. Para o deferimento de indenização por danos morais e materiais em decorrência de acidente do trabalho ou doença ocupacional, devem estar presentes o dano injusto, o nexo de causalidade entre este e a atividade exercida pelo empregado e a conduta dolosa ou culposa da empregadora, conforme preceituam os artigos 159 do antigo CCB e 186 do atual CC. Com efeito, a constatação do nexo de causalidade entre as atividades exercidas e a doença que acometeu o Autor é, segundo o magistério de Sebastião Geraldo de Oliveira, o primeiro pressuposto a ser investigado, "porquanto se o acidente não estiver relacionado ao trabalho é desnecessário, por óbvio, analisar a extensão dos danos e a culpa patronal" (in Indenizações por acidente do trabalho ou doença ocupacional. $2^{a}$ ed. São Paulo: LTR. 2006. p. 124)”.
} 
repercussão física por conta do assédio moral além de fazer jus ao benefício previdenciário do auxílio-doença acidentário, gozará de garantia no emprego, a teor do artigo 118 da lei $n^{\circ}$ 8.213/91. Tudo isso, sem elidir a responsabilidade civil do empregador ${ }^{98}$, conforme, aliás, expressão jurisprudencial sumulada no enunciado de $\mathrm{n}^{\circ} 299$ do colendo STF. A indenização a título de danos materiais e, se for o caso, morais, em face do acidente de trabalho, in casu, doença ocupacional, não se confunde com os valores percebidos pelo trabalhador do Instituto Previdenciário.

Todos esses distúrbios à saúde do trabalhador, provocados pelas circunstâncias a que foi submetido durante o assédio moral, devem ser levados em conta, ainda, para a quantificação do dano moral. Ademais, a questão da fixação do valor de tal reparação suscita dúvida. O Projeto de Lei n 150/99 do Senado Federal tenta estipular parâmetros para tarifar o dano moral, mas tem recebido duras críticas, por engessar demais a atividade jurisdicional no estudo do caso concreto.

Com ampla aceitação jurisprudencial, João Oreste Dalazan ${ }^{99}$ e Teixeira Lima ${ }^{100}$ concordam que alguns aspectos deverão ser levados em conta pelo magistrado no momento da fixação do quantum indenizatório, a saber: (i) extensão do dano, no aspecto social, já que por residir na esfera íntima da

(TRT3, RO - 00840-2005-100-03-00-7, Rel. Juiz Luiz Otávio Linhares Renault, Minas Gerais, 28 jun. 2007).

98 Eis os fundamentos do acórdão ora enfrentado, oriundo do Tribunal Regional do Trabalho da $23^{\mathrm{a}}$ Região, para chegar a tais conclusões: “A Constituição da República prevê em seu artigo $7^{\circ}$, inciso XXVIII, que caberá à empresa indenizar o trabalhador por danos decorrentes de acidente de trabalho, independentemente do seguro a cargo do empregador. Defluo que o legislador constituinte originário fez questão de consignar a existência de diferença entre a pensão a ser suportada pela empresa e o benefício previdenciário custeado pelo INSS, em caso de acidente de trabalho ocasionado por culpa ou dolo da Empregadora. Tais pensões se diferem quanto à origem e quanto à finalidade. A pensão decorrente da responsabilidade civil tem esteio legal no Código Civil e tem como finalidade ressarcir a vítima pelos danos materiais sofridos no que diz respeito aos lucros cessantes. Já a pensão custeada pelo INSS tem origem na legislação previdenciária, servindo como um benefício social ou um seguro social, custeado pelos trabalhadores, empregadores e pela sociedade, contra acidentes sofridos pelo trabalhador, cujo objetivo é tão-somente garantir um benefício de cunho estritamente alimentar”.

${ }^{99}$ DALAZEN, João Oreste. Aspectos do dano moral trabalhista. Revista do Tribunal Superior do Trabalho. Porto Alegre, ano 65, nº 1, pp 78-79, out/dez 1999.

100 TEIXEIRA, João Lima et al. Op. cit. pp. 633-638. 
vítima, é incomensurável quanto a ela; (ii) duração do sofrimento; (iii) intenção do agente; (iv) aspectos pessoais e econômicos do agressor; (v) razoabilidade. É preciso sublinhar, de toda forma, que os tribunais vêm entendendo o dano moral como uma punição educativa ${ }^{101}$, e não um meio de enriquecer a vítima.

Noutro giro, deve-se salientar que o assédio moral pode lesionar, como exposto acima, o direito de um só trabalhador que, isoladamente, a vítima das investidas perversas do empregador, mas também, de uma coletividade indeterminada. Afinal, a violência moral pode consistir numa forma de gestão injuriosa, direcionada a todo o quadro funcional da empresa, o que deixa o ambiente laboral, tomado como um todo, insustentável para qualquer trabalhador, e não apenas para um ou outro.

Cumpre ressaltar também que a prática do assédio moral também traz à tona a questão do dano moral coletivo, configurado quando o patrimônio imaterial de um grupo determinado ou determinável de indivíduos é maculado. Essa gama subjetiva de valores - que se convencionou chamar de direitos transindividuais e cujo conceito consta do artigo 81, inciso II, da lei $n^{\circ}$ 8.078/ 90, o Código de Defesa do Consumidor -, são, pois, direitos indivisíveis, titularizados por um grupo que guarda, entre si, certo liame jurídico de identidade. No texto da norma precitada, para afastar qualquer suspeita, a relação empregatícia é citada como exemplo.

Uma vez constatada lesão a direito transindividual dos trabalhadores, o socorro processual legítimo para reparação do dano moral coletivo é a ação

\footnotetext{
${ }^{101}$ DANO MORAL. INDENIZAÇÃO. A natureza da indenização decorrente do dano moral é de punição educativa ao agressor, de forma a inibir a repetição do mesmo ato no futuro. Por isso, deve levar em conta a intensidade do ato, os antecedentes e a capacidade econômica do empregador. Não tem finalidade de enriquecer a vítima. (TRT1, RO 02801-2001-243-01-00-8, Rel. Juíza Vólia Bonfim Cassar, Rio de Janeiro, 29 jun. 2005).

O arbitramento há de ser feito de modo a satisfazer, a um só tempo, o interesse de compensação ao lesado, de um lado, e a repressão à conduta do agressor, de outro. Deve conferir um sentido de expressão equilibrada a esses dois pólos. Uma indenização insignificante representaria um agravamento ao ofendido e sentido de impunidade ao ofensor. Uma indenização escorchante
} 
civil pública, de que cuida a lei $n^{\circ} 7.347 / 85$, com supedâneo no inciso IV do artigo $1^{\circ}$ da norma citada. O brilhantismo desse instrumento reside na sua legitimação: sendo proposta pelo Ministério Público, ainda que por denúncia de um trabalhador ofendido, a identidade deste fica resguardada por sigilo. É de se festejar isso, porque livra o trabalhador de perseguições no âmbito da empresa, como demissões a inclusão em listas negras.

A Lei Complementar $n^{\circ}$ 75, de 20 de maio de 1993, que trata das atribuições do Ministério Público Federal, inclui, no seu artigo 83, inciso III, como competência do insigne órgão, o ajuizamento de ações civis públicas na seara trabalhista. 


\section{Conclusão}

Uma observação mais detida sobre o assédio moral no ambiente de trabalho permite o reconhecimento do curso regular e necessário do poder ao longo do liame empregatício, bem como o papel que ele vai desempenhando nos diferentes níveis de interação humana dentro da empresa. Significa dizer que em todas as esferas de contato dos trabalhadores - seja entre seus pares, com seus superiores hierárquicos ou subalternos -, o poder institucional se manifesta inevitavelmente, como produto natural da convivência produtiva.

Poder e trabalho organizado são elementos indissociáveis, conforme demonstra a construção história da atividade humana voltada para a produção e para a estrutura econômica. Ocorre que a capacidade de produzir e os meios para organiza-la dificilmente ocupam o mesmo pólo da relação trabalhista, e a instabilidade desse distanciamento viabiliza - quiçá estimula -, tentativas de dominação.

Tais esforços, nos exórdios da sociedade, legitimavam-se pela violência, através de regimes escravocratas, fundados na supressão da liberdade e coisificação do trabalhador. Contudo, com o progresso da humanidade, ganhou contornos de licitude, através do instrumento formal do contrato. Este contrato de trabalho - sobretudo em sua espécie mais afamada, o de emprego -, é marcado pela bilateralidade e pela desproporção de forças entre as partes, e, por isso mesmo, em última análise,vem a legitimar o estado de subordinação do empregado ao empregador. Afinal, uma vez firmado o pacto, o obreiro, conscientemente, entrega sua força laborativa a serviço do empreendimento alheio, sujeitando-se aos ditames deste.

Por outro lado, o poder não se limita ao empreendedor, que é o empregador direto. É imperioso admitir que ele se espalha em todos os núcleos 
da produção, servindo em menor ou maior escala a diferentes integrantes da atividade produtiva. Em outras palavras, deve-se admitir que é possível fracionar o poder, em tantos quantos forem os núcleos de organização da atividade, e isto o torna objeto de acirradas disputas, corrompendo-o.

São muitas as fontes de onde se pode esperar que emane o poder corrompido, que é o que está apto para provocar o assédio moral. Sobressai, de maneira quase absoluta, a dependência jurídica, e não econômica, ou técnica, como demonstrado em capítulo apropriado, que o empregado tem ante seu empregador, que resume-se em verdadeira hipossuficiência.

Contudo, outras possibilidades podem ser cogitadas, como contatos pessoais, reputação pública, conhecimento sobre detalhes da vida do outro são meios de se exercer domínio sobre alguém, ainda que não se possa comandá-la diretamente. Destarte, é patente que o poder dentro da lógica institucional de uma empresa pode assumir diversas vertentes.

Em quaisquer dessas perspectivas, o poder fertiliza mais ainda o terreno para práticas violentas quando inserido na moderna organização do trabalho. Esta é marcada pela ferocidade da competitividade, manifestada, na rotina empreendedora e trabalhista, por imposição de metas inflexíveis e latência da perda de posto de trabalho para um verdadeiro exército de reserva. Por meio deste, o mercado permanentemente oferece ao empregador a constante renovação de mão de obra.

Assim, a faculdade que é dada a alguém de gerir a produção - toda, quando se trata do próprio empreendedor, ou em parte, no que tange aos diretores setorizados -, deixa de servir ao fim de mantença da saúde do empreendimento, para dar lugar a abominações como o assédio moral. Este, mormente praticado por superiores hierárquicos, ao buscar a desnaturação da vítima como profissional e até mesmo como ser social, revela a brutalidade com que o poder pode surgir dentro da dinâmica trabalhista. 
Pela análise das supra mencionadas finalidades e formas com que se opera a deturpação do poder dentro do ambiente de trabalho, conclui-se que o assédio moral é a mais recorrente e pungente agressão que o trabalhador pode sofrer. Resta comprovada, nessa esteira argumentativa, que o uso das prerrogativas de direção e controle, quando desregradas, culminam na humilhação e conseqüente exclusão, moral e física, do empregado do local de labuta. Assim, o agressor reafirma o estado de sujeição do ex-empregado, e, por via de conseqüência, de todos os demais trabalhadores, legitimando-se como dominador de todo enredo profissional do grupo em que se insere.

Essa busca por espaço empresarial, eliminação de concorrência, angariação de benefícios reservados a outrem, ou, mesmo, acumulação de mais poderes pelo mero fato de ostentá-los, pode trazer resultados nefastos. Estes dizem respeito ao equilíbrio do ambiente profissional, aos rendimentos da atividade e à saúde física e psicológica dos envolvidos no engendro do assédio.

A proposta da leitura do assédio moral a partir da dignidade humana e das relações contratuais de poder se torna, assim, imperiosa. Este tratamento já vem sendo dispensado ao tema não só pela doutrina, mas também pela jurisprudência, a qual vem fixando novos meios de reparação do dano causado ao trabalhador vilipendiado pela violência psicológica. Nesse sentido, pode-se citar a reparação do dano moral, a rescisão indireta do contrato laboral e até mesmo o enquadramento dos transtornos físicos advindos das alterações emocionais do trabalhados ao acidente de trabalho como acidente do trabalho por equiparação.

Esta realidade é da essência do trabalho organizado, independentemente do seu grau de complexidade. No entanto, somente nos dias atuais surge a real preocupação com a questão da violência dentro do ambiente profissional, quando o progresso de um ordenamento jurídico é sinalizado pelo tratamento que ele dispensa ao trabalho humano. 
Afinando neste diapasão, a Constituição Federal de 1988 merece ser festejada. Nela, o labor encontra proteção por variadas perspectivas, que, tomadas em conjunto, estão em um compasso harmonioso. Basta que se atente para o artigo inaugural do texto vindicado, pelo qual a dignidade da pessoa humana recebe status de fundamento desta República. Este reconhecimento, a bem da verdade, chegou com certo atraso. Textos mais antigos, como a Declaração Universal dos Direitos do Homem e do Cidadão, de 1789, ou mesmo obras de pensadores como Immanuel Kant, já tratavam com clareza da necessidade de se reservar ao ser humano tutela especial.

Ressalvado o retardo histórico, a riqueza da Carta Magna vai além. É certo que a garantia ímpar de dignidade a cada cidadão, pelo simples fato de serem homens, atende todas as necessidades de regulamentação da exploração lícita de mão de obra. Sob a égide deste único fundamento é possível assegurar a cada trabalhador remuneração suficiente e ambiente de trabalho equilibrado, por exemplo. Contudo, para aclarar mais a relevância que se reconhece ao labor de seus cidadãos, a Constituição da República inaugurou capítulo específico para tratar do trabalhador, assinalando direitos específicos e inafastáveis.

Considerados e ressaltados estes direitos, não só do homem como, mais especificamente, do trabalhador, é que se torna imperiosa a colocação de entraves no curso do poder dentro do contrato de trabalho. Afinal, ele pode assumir uma face ilícita e violenta, resultado da fragilidade de uma parte desta relação, contraposta aos interesses perversos da outra. Essa realidade traz inquietação, desde muito, à doutrina, e, recentemente, passa a contagiar a jurisprudência.

São nestes âmbitos que surgem, bem demarcadas, duas fases do tratamento a ser dispensado ao assédio moral. Uma primeira, preventiva, cria, para as partes do contrato deveres de caráter principiológico, que buscam essência nas garantias constitucionais suso tratadas. A outra, repressiva, busca 
recompor o equilíbrio e a salubridade da atividade obreira, fazendo cessar o ato lesivo e compensando o trabalhador pela agressão vivida.

Embora, por óbvio, a tratamento preventivo seja sempre o mais recomendado e satisfatório, é durante a análise da repressão que as nuances do assédio moral se tornam menos cinzentas, e sua realidade passa a saltar aos olhos. Isto porque somente se vislumbra, com concretude e clareza, todas as perdas impostas ao assediado quando se busca repará-las.

Nesse sentido, a ruptura indireta do contrato e a configuração do dano moral são medidas incontestes e cujo cabimento não desperta qualquer desassossego. Por outro lado, novidade que ganha força na doutrina e, silenciosamente, já começa repercute na jurisprudência, é o reconhecimento do acidente de trabalho no caso de trabalhadores que, uma vez assediados, passam a padecer de adoecimento clínico comprovado, seja ele corporal ou psicológico.

São pontuais e seguras as correlações feitas para se chegar a esta conclusão. Afinal, leva-se em conta que doenças profissionais, antes de dizerem respeito a uma atividade em si, estão ligadas às condições em que ela se opera. Ou seja, qualquer atividade pode vir a provocar uma doença tida como profissional, se desenvolvida de um modo que, em alguma medida, crie riscos, de qualquer natureza, àquele que a desempenha.

No entanto, não se pode olvidar que é igualmente tortuosa a via aberta. Basta que nos recordemos de um movimento até agora meramente midiático, fomentado por casos verificados, principalmente, em países orientais, mas que, cedo ou tarde, poderá irromper em nossos tribunais: a tentativa de se taxar o suicídio como acidente de trabalho.

Ora, se admitido, como não poderia deixar de ser, que algumas doenças mentais são causadas pelo ambiente violento e psicologicamente degradante criado pelo empregador assediador, em algum momento será inevitável questionar se, numa causalidade indireta, pode-se atribuir a este mesmo 
empregador os atos praticados pelo trabalhador mentalmente debilitado. Esta é uma questão por ora meramente acadêmica, que dentro das limitações metodológicas deste trabalho, não se tem a pretensão de aclarar ou responder.

Ao cabo desse estudo, o que se pretendeu foi trazer à tona a embrionária origem do assédio moral, que reside na formação dos vínculos de poder dentro da lógica laboral. Assentada tal premissa, garante-se maior eficiência no combate à violência contra o trabalhador, que poderá ser enfrentada desde seu princípio, contribuindo, pois, para a construção de um ambiente de trabalho mais salutar e hábil para o desenvolvimento humano e social. 


\section{Bibliografia}

ALKIMIN, Maria Aparecida. Assédio moral na relação de trabalho. 2. ed. rev. atual. Curitiba: Juruá, 2009. 136 p.

- Violência na relação de trabalho e proteção à personalidade do trabalhador. 1. ed. Curitiba: Juruá, 2009. 220 p.

ASSE, Vilja Marques. Um fenômeno chamado psicoterrorismo. Revista LTr, 68, n 7, p. 819-821, jul. 2004.

BARACAT, Eduardo Milléo. A boa-fé no direito individual do trabalho. São Paulo: LTr, 2003. 280 p.

BARRETO, Margarida. Violência, saúde e trabalho: uma jornada de humilhações. São Paulo: PUC, 2003. 233 p.

BARROS, Alice Monteiro de. Curso de direito do trabalho. 2. ed. São Paulo: LTr, 2006. 1.392 p.

. Proteção à intimidade do empregado. São Paulo: LTr, 1997. 208 p.

BELMONTE, Alexandre Agra. Curso de responsabilidade trabalhista: danos morais e patrimoniais na relação de trabalho. 1. ed. São Paulo: LTr, 2008. 256 p. 
O monitoramento da correspondência eletrônica nas relações de trabalho. São Paulo: LTr, 2004. 166 p.

BODIN de MORAES, Maria Celina. O Conceito de Dignidade Humana: Substrato Axiológico e Conteúdo Normativo. In: Ingo W. Sarlet. (Org.). Constituição, Direitos Fundamentais e Direito Privado. 2 ed. Porto Alegre: Livraria do Advogado Editora, 2006. p. 107-151.

CARRION, Valentin. Comentários à consolidação das leis do trabalho. 34. ed. atual. por Eduardo Carrion. São Paulo: Saraiva, 2009. 1.396 p.

CASSAR, Vólia Bonfim. Direito do Trabalho. 3. ed. Niterói: Impetus, 2009. $1.112 \mathrm{p}$.

CASTELO, Jorge Pinheiro. Tutela antecipada no processo do trabalho. São Paulo: LTr, 1999. 384 p.

CAVALIERI FILHO, Sergio. Programa de responsabilidade civil. 7. ed. São Paulo: Atlas, 2007. 562 p.

CECILIA, Silvana Louzada Lamattina. Responsabilidade do empregador por danos à saúde do trabalhador. São Paulo: LTr, 2008. 128 p.

CHAUI, Marilena de Souza. Convite à Filosofia. 12. ed. São Paulo: Ática, 1999. $424 \mathrm{p}$.

COMPARATO, Fábio Konder. A afirmação histórica dos Direitos Humanos. 3. ed. rev. e ampl. São Paulo: Saraiva, 2003. 577 p. 
DALAZEN, João Oreste. Aspectos do dano moral trabalhista. Revista do Tribunal Superior do Trabalho. Porto Alegre, ano 65, no 1, p. 69-84, out/dez 1999.

DAVENPORT, Noa; SCHWARTZ, Ruth Distler; ELLIOT, Gail Pursell. Mobbing: emotional abuse in the american workplace. Iowa: Civil Society Publishing, 2002. 216 p.

DELGADO, Maurício Godinho. Curso de direito do trabalho. 3. ed. São Paulo: LTr, 2004. 1.344 p.

DRAY, Guilherme Machado. O princípio da igualdade no direito do trabalho. Coimbra: Almedina, 1999. 322 p.

GOMES, Orlando; GOTTSCHALK, Elson. Curso de direito do trabalho, 14. ed. Rio de Janeiro: Forense, 1995. 746 p.

GUEDES, Márcia Novaes. Terror psicológico no trabalho. 2. ed. São Paulo: LTr, 2005. 176 p.

HIRIGOYEN, Marie-France. Mal-estar no trabalho: redefinindo o assédio moral. Rio de Janeiro: Bertrand Brasil, 2002. 350 p.

LOPES. Manuel Carlos Palomeque. Direito do trabalho e ideologia. Tradução de António Moreira. Coimbra: Almedina, 2001. 221 p.

MELGAR, Alfredo Montoya. Derecho del trabajo. 2. ed. Madrid: Tecnos, 2001. 840 p. 
MELO, Raimundo Simão de. Direito ambiental do trabalho e saúde do trabalhador: responsabilidades legais, dano material, dano moral, dano estético e perda de uma chance. 2. ed. São Paulo: LTr, 2006. 472 p.

MENDES, Gilmar Ferreira; COELHO, Inocêncio Mártires; BRANCO, Paulo Gustavo Gonet. Curso de Direito Constitucional. 2 ed. São Paulo: Saraiva, 2008. 1.435 p.

MENDES, Gilmar Ferreira. Direitos fundamentais $e$ controle de constitucionalidade: estudos de direito constitucional. 2. ed. rev. e ampl. São Paulo: Instituto Brasileiro de Direito Constitucional, 1999. 484 p.

MENEZES, Cláudio Armando Couce. Assédio moral. Revista Síntese Trabalhista. Porto Alegre, n. 169, p. 140-150, jul. 2003.

MORAES FILHO, Evaristo de; MORAES, Antonio Carlos Flores de. Introdução ao direito do trabalho. 7. ed. São Paulo: LTr, 1995. 820 p.

NACIMENTO, Amauri Mascaro. Direito do trabalho na constituição de 1988. São Paulo: Saraiva, 1989. 320 p.

Curso de direito do trabalho. 22. ed. rev. e atual. São Paulo: Saraiva, 2007. 1.301 p.

NASCIMENTO, Sonia Mascaro. O assédio moral no ambiente de trabalho. Revista LTr. São Paulo, nº 8, p. 924, ano 2004.

PINTO, José Augusto Rodrigues. Curso de direito individual do trabalho. 2. ed. São Paulo: LTr, 1995. 664 p. 
PRUNES, José Luiz Ferreira. Justa causa e despedida indireta. Curitiba: Juruá, 1994. 554 p.

REALE, Miguel. Filosofia do Direito. 19. ed. São Paulo: Saraiva, 2002. 360 p.

RIVERO, Jean; FAVOREU, Louis. Tribunales constitucionales europeos y derechos fundamentales. Madrid: CEC, 1984. 568 p.

ROMITA, Arion Sayão. A subordinação no contrato de trabalho. Rio de Janeiro: Forense, 1979. 116 p.

Direitos Fundamentais na Relação de Trabalho. São Paulo: LTr, 2005. $472 \mathrm{p}$.

ROUSSEAU, Jean-Jacques. Discurso sobre a origem das desigualdades entre os homens. São Paulo: Nova Cultural, 1987. 143 p.

SAMPAIO, Aluysio. Fundo de garantia de tempo de serviço e estabilidade com indenização. São Paulo: Editora RT, 1971. 335 p.

SENNETT, Richard. A corrosão do caráter: as conseqüências pessoais do trabalho no novo capitalismo. Trad. Marcos Santarrita. Rio de Janeiro: Record, 1999. $203 \mathrm{p}$.

SILVA, Carlos Alberto Barata. Compêndio de direito do trabalho. 4. ed. São Paulo: LTr, 1986. 480 p. 
SILVA, José Afonso. Curso de direito constitucional positivo. 24. ed. São Paulo: Malheiros, 2004. 925 p.

STF, ADI 1946/ DF, Rel. Min. Sidney Sanches, Brasília, 03 abril 2003.

STF, RE 201819/ RJ, Rel. Min. Ellen Gracie, Brasília, 11 out. 2005.

SÜSSEKIND, Arnaldo. Curso de Direito do Trabalho. 2. ed. rev. e atualiz. Rio de Janeiro: Renovar, 2004. 645 p.

TEIXEIRA, João de Lima; MARANHÃO, Délio; VIANNA, SEGRADAS; SÜSSEKIND, Arnaldo. Instituições de direito do trabalho. 22. ed. São Paulo: LTr, 2005. vol 1. 702 p.

TJMG, Processo 2004.009529-2, Rel. Paulo Alfeu Puccinelli, Minas Gerais, 10 nov. 2004.

TRF 2. ${ }^{a}$ Região, Apelação Cível 284200, Rel. Arnaldo Lima, Rio de Janeiro, 21 mar. 2003.

TRF 4. ${ }^{a}$ Região, Apelação Cível 9104262077, Rel. Ronaldo Luiz Ponzi, Rio Grande do Sul, 22 nov. 1994.

TRT1, RO 02801-2001-243-01-00-8, Rel. Vólia Bonfim Cassar, Rio de Janeiro, 29 jun. 2005.

TRT17, RO 1315.2000.00.17.00.1, Rel. Sonia das Dores Dionízio, Espírito Santo, 20 ago. 2002. 
TRT18, RO 00653-2006-004-18-00-0, Rel. Marilda Jungman G. Daher, Goiás, 17 out. 2007.

TRT2, RO 00457-2008-038-02-00-1, Rel. Ricardo Artur Costa e Trigueiros, São Paulo, 03 jul. 2009.

TRT2, RO 20020005096, Rel. Jucirema Maria Godinho Gonçalvez, São Paulo, 12 nov. 2002.

TRT3, RO 00099-2005- 111-03-00-8, Rel. Alves Horta, Minas Gerais, 22 out. 2005.

TRT3, RO 00105-2004-089-03-00-0, Rel. Olívia Figueiredo Pinto Coelho, Minas Gerais, 28 jul. 2004.

TRT3, RO 00809-2007-131-03-00-6, Rel. Irapuan de Oliveira Teixeira Lyra, Minais Gerais, 14 nov. 2007.

TRT3, RO - 00840-2005-100-03-00-7, Rel. Luiz Otávio Linhares Renault, Minas Gerais, 28 jun. 2007.

TRT23, RO - 01040.2007.003.23.00-7, Rel. Liz Alcântara, Mato Grosso, 29 out. 2008.

TRT23, RO - 01815.2007.051.23.00-8, Rel. Luiz Alcântara, Mato Grosso, 05 nov. 2008. 
TRT23, RO - 01040.2007.003.23.00-7, Rel. Liz Alcântara, Mato Grosso, 29 out. 2008.

TRT23, RO - 01815.2007.051.23.00-8, Rel. Luiz Alcântara, Mato Grosso, 05 nov. 2008.

TRT4, RO 00149-2005-025-04-00-6, Relator Juiz Milton Varela Dutra, Rio Grande do Sul, 24 jun. 2007.

TST, AIRR-1.542/2005-055-02-40.4, Rel. Ives Gandra, Brasília, 06 de jun. 2008.

TST, AIRR-211/2006-343-01-40.8, Rel. Rosa Maria Weber Candiota da Rosa, Brasília, 25 jun. 2009.

TST, AIRR 653/2006-004-18-40, Rel. Walmir Oliveira da Costa, Brasília, 04 fev. 2009.

TST, RR-1044/2003-039-02-00.6, Rel. Aloysio Corrêa da Veiga, Brasília, 19 ago. 2009.

TST, RR - 12165/2003-008-09-00.7, Rel. Horácio Raymundo de Senna Pires, Brasília, 26 ago. 2009.

TST, RR - 1455/2004-005-09-00.7, Rel. Aloysio Corrêa da Veiga, Brasília, 05 ago. 2009.

TST, RR 20024.2003.001.09.00-3, Rel. Renato de Lacerda Paiva, Brasília, 23. set. 2009. 
TST, RR - 960/2005-011-03-00.0, Rel. Alberto Luiz Bresciani de Fontan Pereira, Brasília, 24 jun. 2009.

TST, RR - 9961/2004-015-09-00.1, Rel. Ives Gandra Martins Filho, Brasília, 18 fev. 2009.

WEBER, Max. Ensaios de sociologia. Organizado por H. H. Gerth e C. Wrigth Mills. Tradução de Waltersin Dutra. 5. ed. Rio de Janeiro: LTC, 2002. 325 p.

ZABALA, Iñaki Piñuel y. Mobbing: como sobreviver ao assédio psicológico no trabalho. Trad. Alda Machado. São Paulo: Loyola, 2003. 312 p. 